\title{
Can macroalgae provide promising anti-tumoral compounds? A closer look at Cystoseira tamariscifolia as a source for antioxidant and anti-hepatocarcinoma compounds
}

Catarina Vizetto-Duarte, Luísa Custódio, Gerardo Acosta, João H G Lago, Thiago R Morais, Carolina Bruno de Sousa, Katkam N Gangadhar, Maria João Rodrigues, Hugo Pereira, Raquel T Lima, M. Helena Vasconcelos, Luísa Barreira, Amélia P Rauter, Fernando Albericio, João Varela

Marine organisms are a prolific source of drug leads in a variety of therapeutic areas. In the last few years, biomedical, pharmaceutical and nutraceutical industries have shown growing interest in novel compounds from marine organisms, including macroalgae. Cystoseira is a genus of Phaeophyceae (Fucales) macroalgae known to contain bioactive compounds. Organic extracts (hexane, diethyl ether, ethyl acetate and methanol extracts) from three Cystoseira species ( $C$. humilis, $C$. tamariscifolia and $C$. usneoides) were evaluated for their total phenolic content, radical scavenging activity against 2,2-diphenyl1-picrylhydrazyl (DPPH) and 2,2'-azino-bis(3-ethylbenzothiazoline-6-sulphonic acid) (ABTS) radicals, and antiproliferative activity against a human hepatocarcinoma cell line (HepG2 cells). $C$. tamariscifolia had the highest TPC and RSA. The hexane extract of $C$. tamariscifolia $(\mathrm{CTH})$ had the highest cytotoxic activity (IC50 $=2.31 \mu \mathrm{g} / \mathrm{mL}$ ), and was further tested in four human tumor (cervical adenocarcinoma HeLa; gastric adenocarcinoma AGS; colorectal adenocarcinoma HCT-15; neuroblastoma SH-SY5Y), and two non-tumor (murine bone marrow stroma S17 and human umbilical vein endothelial HUVEC) cell lines in order to determine its selectivity. CTH strongly reduced viability of all tumor cell lines, especially of HepG2 cells. Cytotoxicity was particularly selective for the latter cells with a selectivity index $=12.6$ as compared to non-tumor cells. Incubation with CTH led to a 2-fold decrease of HepG2 cell proliferation as shown by the bromodeoxyuridine (BrdU) incorporation assay. CTH-treated HepG2 cells presented also pro-apoptotic features, such as increased Annexin V/propidium iodide (PI) binding and dose-dependent morphological alterations in DAPI-

stained cells. Moreover, it had a noticeable disaggregating effect on 3D multicellular tumor spheroids. Demethoxy cystoketal chromane, a derivative of the meroditerpenoid cystoketal, was identified as the active compound in CTH and was shown to display selective in vitro cytotoxicity towards HepG2 cells. 
1 Can macroalgae provide bioactive compounds with pharmaceutical potential? A closer look

2 at Cystoseira tamariscifolia as a source for antioxidant and anti-hepatocarcinoma 3 compounds

4 Catarina Vizetto-Duarte ${ }^{1}$, Luísa Custódio ${ }^{1}$, Gerardo Acosta ${ }^{2,3}$, João Henrique G. Lago ${ }^{4}$,

5 Thiago R. Morais ${ }^{4}$, Carolina Bruno de Sousa ${ }^{1}$, Katkam N. Gangadhar,5, Maria João 6 Rodrigues $^{1}$, Hugo Pereira ${ }^{1}$, Raquel T. Lima ${ }^{6,7,8}$, M. Helena Vasconcelos ${ }^{6,7,9}$, Luísa Barreira ${ }^{1}$, 7 Amélia P. Rauter ${ }^{10}$, Fernando Albericio ${ }^{2,3,11}$ and João Varela ${ }^{1 *}$

$8{ }^{1}$ Centre of Marine Sciences, University of Algarve, Faculty of Sciences and Technology, Ed. 7,

9 Campus of Gambelas, Faro, Portugal ${ }^{2}$ Institute for Research in Biomedicine of Barcelona, 10 Chemistry and Molecular Pharmacology, Barcelona Science Park, Baldiri Reixac 10, 08028, 11 Barcelona, Spain ${ }^{3}$ CIBER-BBN, Networking Centre on Bioengineering, Biomaterials and 12 Nanomedicine, Barcelona Science Park, Baldiri Reixac 10, 08028 Barcelona, Spain ${ }^{4}$ Institute of 13 Environmental, Chemical and Pharmaceutical Sciences, Federal University of Sao Paulo, 0997214 270, Sao Paulo, Brazil ${ }^{5}$ Instituto de Tecnologia Química e Biológica, Universidade Nova de Lisboa, Avenida da Republica, Oeiras 2780-157, Portugal 6i3S - Instituto de Investigação e Inovação em Saúde da Universidade do Porto, Rua Alfredo Allen 208, 4200 - 135 Porto, Portugal ${ }^{7}$ Cancer Drug Resistance Group, IPATIMUP - Institute of Molecular Pathology and Immunology of the University of Porto, Rua Júlio Amaral de Carvalho, 45, 4200-135 Porto, Portugal ${ }^{8}$ Department of Pathology and Oncology, Faculty of Medicine of the University of Porto, Porto, Portugal, Alameda Prof. Hernâni Monteiro, 4200-319 Porto, Portugal ${ }^{9}$ Department of Biological Sciences, Faculty of Pharmacy, University of Porto, Rua de Jorge Viterbo Ferreira $n^{\circ} 228,4050$ 313 Porto, Portugal ${ }^{10}$ Center of Chemistry and Biochemistry, Department of Chemistry and Biochemistry, Faculty of Sciences University of Lisbon, Campo Grande, Ed. C8, Piso 5, 1749016 Lisbon, Portugal Barcelona, Spain.

*Corresponding author. Address: Centre of Marine Sciences, University of Algarve, Faculty of 800900 ext. 7381; fax: +351 289 818353, E-mail address: jvarela@ualg.pt (João Varela). 
$30 \quad$ Abstract

31 Marine organisms are a prolific source of drug leads in a variety of therapeutic areas. In the last

32 few years, biomedical, pharmaceutical and nutraceutical industries have shown growing interest

33 in novel compounds from marine organisms, including macroalgae. Cystoseira is a genus of

34 Phaeophyceae (Fucales) macroalgae known to contain bioactive compounds. Organic extracts

35 (hexane, diethyl ether, ethyl acetate and methanol extracts) from three Cystoseira species $(C$.

36 humilis, C. tamariscifolia and C. usneoides) were evaluated for their total phenolic content,

37 radical scavenging activity against 2,2-diphenyl-1-picrylhydrazyl (DPPH) and 2,2'-azino-bis(3-

38 ethylbenzothiazoline-6-sulphonic acid) (ABTS) radicals, and antiproliferative activity against a

39 human hepatocarcinoma cell line (HepG2 cells). C. tamariscifolia had the highest TPC and RSA.

40 The hexane extract of $C$. tamariscifolia $(\mathrm{CTH})$ had the highest cytotoxic activity (IC50=2.31

$41 \mu \mathrm{g} / \mathrm{mL}$ ), and was further tested in four human tumor (cervical adenocarcinoma HeLa; gastric

42 adenocarcinoma AGS; colorectal adenocarcinoma HCT-15; neuroblastoma SH-SY5Y), and two

43 non-tumor (murine bone marrow stroma S17 and human umbilical vein endothelial HUVEC) cell

44 lines in order to determine its selectivity. CTH strongly reduced viability of all tumor cell lines,

45 especially of HepG2 cells. Cytotoxicity was particularly selective for the latter cells with a

46 selectivity index $=12.6$ as compared to non-tumor cells. Incubation with CTH led to a 2-fold

47 decrease of HepG2 cell proliferation as shown by the bromodeoxyuridine (BrdU) incorporation

48 assay. CTH-treated HepG2 cells presented also pro-apoptotic features, such as increased Annexin

$49 \mathrm{~V} /$ propidium iodide (PI) binding and dose-dependent morphological alterations in DAPI-stained

50 cells. Moreover, it had a noticeable disaggregating effect on 3D multicellular tumor spheroids.

51 Demethoxy cystoketal chromane, a derivative of the meroditerpenoid cystoketal, was identified

52 as the active compound in $\mathrm{CTH}$ and was shown to display selective in vitro cytotoxicity towards

53 HepG2 cells. 
54

55

56

57

58

59

60

61

62

\section{Introduction}

Macroalgae are used as food and feed, and also as sources of bioactive metabolites. In particular, Phaeophyceae algae have high contents of polysaccharides, minerals, polyunsaturated fatty acids and vitamins (Balboa et al., 2013). Furthermore, these organisms contain high levels of secondary metabolites with pharmacological interest, such as terpenoids, phenolic compounds and alkaloids, which have been linked to interesting biomedical activities, including antitumoral and neuroprotective (Smit, 2004; Blunt et al., 2014). Among Phaeophyceae, the Cystoseira genus comprises a large number of species widely distributed in the Atlantic and Mediterranean Sea (Guiry and Guiry, 2015). Phytochemical studies have revealed that species belonging to this genus are rich in phlorotannins, sterols, meroditerpenoids and sesquiterpenoids (Amico, 1995; Moreno et al., 1998; Khanavi et al., 2012; Sathya et al., 2013; Montero et al., 2014), some of which exhibiting antioxidant, antitumoral, antifouling and/or antimicrobial activities with potential applications in the pharmaceutical industry (Amico, 1995; Gouveia et al., 2013; Valls and Piovetti, 1995).

Phaeophyceae algae have already shown interesting biomedical properties such as Dictyota ciliolata, Padina sanctae-crucis, Turbinaria tricostata and Petalonia fascia with antiproliferative activity in cancer cell lines (Caamal-Fuentes et al., 2014; Kurt et al., 2014). Cystoseira and Fucus genus are also known to contain molecules with antioxidant properties (Mhadhebi et al., 2011; Heffernan et al., 2015; Hadj Ammar et al., 2015). Bearing in mind the high biotechnological potential of brown algae, in this work we evaluated the total phenolic contents and antioxidant activity of organic extracts of $C$. tamariscifolia, C. humilis and C. usneoides. The antiproliferative potential was screened on human hepatocellular carcinoma HepG2 cells, a cell line known to be recalcitrant to cytotoxic drugs (Liu et al., 2010). The most bioactive extract $(C$. tamariscifolia hexane extract; named $\mathrm{CTH}$ ) was also evaluated in several other human tumor cell lines and compared to non-tumor cells used as selectivity controls. Cytotoxicity was then further 
79 studied in terms of its action on cell proliferation inhibition and apoptosis induction, important

80 features for potential anti-cancer therapies. It was also evaluated its effect on multicellular tumor

81 spheroids (MCTS). This extract was then subjected to a bioactivity-guided fractionation to afford

82 the meroditerpene demethoxy cystoketal chromane, which was bioactive against HepG2 cell line.

\section{2. Material and Methods}

84 2.1. General. Hexane, ethyl acetate (EtOAc) and diethyl ether were from Prolabo (VWR 85 International, Leuven, Belgium). Roswell Park Memorial Institute medium (RPMI), Dulbecco's

86 Modified Eagle's medium (DMEM), fetal bovine serum (FBS), L-glutamine and 87 penicillin/streptomycin were obtained from Lonza Ibérica (Barcelona, Spain). 2,2'-azino-bis(3ethylbenzothiazoline-6-sulphonic acid (ABTS) and 3-(4,5-dimethylthiazol-2-yl)-2,5diphenyltetrazolium bromide (MTT) were obtained from AppliChem and Calbiochem, respectively. 1,1-diphenyl-2-picrylhydrazyl (DPPH), potassium persulfate, sodium carbonate and

91 bromodeoxyuridine (BrdU) were purchased from Sigma-Aldrich (Steinheim, Germany). Mouse anti-BrdU antibody was acquired from Dako (Glostrup, Denmark). Vectashield mounting medium for fluorescence with 4',6-diamidino-2-phenylindole (DAPI) was acquired from Vector Laboratories Inc., Peterborough, UK. Merck (Darmstadt, Germany) supplied dimethyl sulphoxide (DMSO), trichloroacetic acid (TCA) and Folin-Ciocalteu (F-C) reagent, whereas methanol was from Fisher Scientific (Loughborough, UK). FITC-conjugated Annexin V/ propidium iodide (PI) assay kit was acquired from Cayman Chemical Company, USA. Silica gel (Merck, 40-63 $\mu \mathrm{m}$ mesh) was used for column chromatographic separation, while silica gel $60 \mathrm{PF}_{254}$ (Merck) was used for analytical $(0.25 \mathrm{~mm})$ TLC. DMSO-d ${ }_{6}$ (Aldrich) was used as solvent for ${ }^{1} \mathrm{H}$ and ${ }^{13} \mathrm{C}$ NMR spectra acquisition and TMS (Aldrich) was used as internal standard. 1D and 2D NMR spectra

101 were recorded at Bruker Digital Avance $800 \mathrm{MHz}$ spectrometer. Additional reagents and 102 necessary solvents were purchased from VWR International (Leuven, Belgium). 
103 2.2. Sampling. Samples of C. tamariscifolia, C. humilis and C. usneoides were collected in the

104 middle/lower intertidal areas, during the low tide, between May and September 2012 on the

105 Portuguese coast. Identification of specimens was made by Dr. Aschwin Engelen (Centre of

106 Marine Sciences, University of Algarve, Portugal) and Dr. Javier Cremades Ugarte (Facultade de

107 Ciencias, University of A Coruña). Voucher specimens of $C$. humilis (code number MB007), $C$.

108 tamariscifolia (code number MB016) and C. usneoides (code number MB013) are deposited at

109 the Centre of Marine Sciences, University of Algarve. Biomass was cleaned with distilled water

$110\left(\mathrm{dH}_{2} \mathrm{O}\right)$ and macroscopic epiphytes and extraneous matter were carefully removed. Samples were

111 freeze-dried and stored at $-20^{\circ} \mathrm{C}$ until the extraction procedure.

112 2.3. Preparation of the Extracts. The extracts were prepared by sequential extraction with 113 solvents of increasing polarities index $(\mathrm{PI})$, namely hexane $(\mathrm{PI}=0.1)$, diethyl ether $(\mathrm{PI}=2.8)$, 114 ethyl acetate $(\mathrm{PI}=4.4)$ and methanol $(\mathrm{PI}=5.1)$. Biomass was mixed with hexane $(1: 10, \mathrm{w} / \mathrm{v})$ and 115 homogenized for 2 min using a disperser IKA T10B Ultra-Turrax at room temperature (RT). The 116 tubes were then vortexed for $1 \mathrm{~min}$, centrifuged $(5000 \mathrm{~g}, 10 \mathrm{~min}, \mathrm{RT})$ and the supernatants 117 recovered. The extraction procedure was repeated 3 times and the supernatants combined and 118 filtered. The residue was then sequentially extracted with diethyl ether, ethyl acetate and 119 methanol as described above. The organic extracts were dried at $40^{\circ} \mathrm{C}$ under vacuum. All extracts 120 were dissolved in DMSO for biological activities screening or in the adequate solvent for 121 chemical characterization, aliquoted and stored $\left(-20^{\circ} \mathrm{C}\right)$. (Velioglu et al., 1998). Briefly, $5 \mu \mathrm{L}$ of the extracts at the concentration of $10 \mathrm{mg} / \mathrm{mL}$ were mixed 124 with $100 \mu \mathrm{L}$ of a 10 -fold diluted F-C reagent, incubated at RT for 5 min and mixed with $100 \mu \mathrm{L}$ 
125 of sodium carbonate $(75 \mathrm{~g} / \mathrm{L}$, w/v). After a $90 \mathrm{~min}$ incubation period at $\mathrm{RT}$, absorbance was 126 measured at $725 \mathrm{~nm}$ on a microplate reader (Biotek Synergy 4). The amount of TPC was 127 calculated as gallic acid equivalents (GAE) using a calibration curve prepared with gallic acid 128 standard solutions, and expressed as GAE in milligrams per gram of dried extract.

129

130

\subsection{Antioxidant activity}

2.5.1. Radical-scavenging activity (RSA) against DPPH. RSA against the DPPH radical was determined according to the method described by Brand-Williams et al. (1995) adapted to 96well microplates (Moreno et al., 2006). Samples $(22 \mu \mathrm{L})$ at concentrations ranging from 0.125 to $10 \mathrm{mg} / \mathrm{mL}$ were mixed with $200 \mu \mathrm{L}$ of DPPH solution $(120 \mu \mathrm{M})$ in methanol and incubated in darkness at RT for $30 \mathrm{~min}$. The absorbance was measured at $515 \mathrm{~nm}$ (Biotek Synergy 4) and results expressed as antioxidant activity (\%) relative to a control containing DMSO and as half maximal inhibitory concentration $\left(\mathrm{IC}_{50}, \mathrm{mg} / \mathrm{mL}\right)$. Butylated hydroxytoluene (BHT, E320) was used as a positive control at the same concentrations of the extracts.

2.5.2. RSA against ABTS. RSA against ABTS was evaluated according to Re et al. (1999). A stock solution of $\mathrm{ABTS}^{\bullet}(7.4 \mathrm{mM})$ was prepared in potassium persulfate $(2.6 \mathrm{mM})$ as the oxidizing agent, and placed in darkness for $12-16 \mathrm{~h}$ at RT. The ABTS ${ }^{+}$solution was diluted with ethanol down to an absorbance of 0.7 units at $734 \mathrm{~nm}$ on a Biotek Synergy 4 microplate reader. Samples $(10 \mu \mathrm{L})$ at concentrations ranging from 0.125 to $10 \mathrm{mg} / \mathrm{mL}$ were mixed with $190 \mu \mathrm{L}$ of $\mathrm{ABTS} \bullet^{+}$ solution in 96-well flat bottom microtitration plates, and 6 min upon mixing absorbance was read at $734 \mathrm{~nm}$. Results were expressed as antioxidant activity (\%) relative to a DMSO-containing control and as $\mathrm{IC}_{50}$ values $(\mathrm{mg} / \mathrm{mL})$. BHT was used as a positive control at the same concentrations of the extracts. 
147 2.6. Cell Lines and Culture Conditions. Human hepatocellular carcinoma HepG2 (ATCC® HB148 8065 $5^{\mathrm{TM}}$ ), human cervix adenocarcinoma HeLa (ATCC $\AA \quad$ CCL-2 ${ }^{\mathrm{TM}}$ ), human gastric 149 adenocarcinoma AGS (ATCC $\left(\right.$ CRL-1739 ${ }^{\mathrm{TM}}$ ) and human colorectal adenocarcinoma HCT-15 150 (ATCC $\AA$ CCL-225 ${ }^{\mathrm{TM}}$ ) cell lines were maintained in RPMI-1640 culture media supplemented 151 with 10\% FBS (v/v), L-glutamine $(2 \mathrm{mM})$, penicillin $(50 \mathrm{U} / \mathrm{mL})$ and streptomycin $(50 \mu \mathrm{g} / \mathrm{mL})$. 152 Murine bone marrow stromal S17 cell line was kindly provided by D. Rawlings, UCLA, Los 153 Angeles, CA. The latter cell line as well as human umbilical vein endothelial HUVEC (ATCC®) 154 CRL-1730 ${ }^{\mathrm{TM}}$ ) and human neuroblastoma SH-SY5Y (ATCC® CRL-2266 ${ }^{\mathrm{TM}}$ ) cell lines were 155 grown in DMEM culture media supplemented with 10\% FBS (v/v), L-glutamine (2 mM), 156 penicillin $(50 \mathrm{U} / \mathrm{mL})$ and streptomycin $(50 \mu \mathrm{g} / \mathrm{mL})$. All cells were grown in an incubator at $37^{\circ} \mathrm{C}$ 157 and $5.0 \% \mathrm{CO}_{2}$ in humidified atmosphere.

2.7. In vitro cytotoxic activity and selectivity. In vitro cytotoxic activity of the extracts was assessed by the MTT colorimetric assay (Mosmann, 1983). Briefly, exponentially growing cells were seeded at a density of $5 \times 10^{3}$ cells/well on 96-well plates and incubated for $24 \mathrm{~h}$ at $37^{\circ} \mathrm{C}$ in $5.0 \% \mathrm{CO}_{2}$. The extracts were then applied at concentrations ranging from 125 to $3.9 \mu \mathrm{g} / \mathrm{mL}$ for $72 \mathrm{~h}$ and cytotoxicity was evaluated. Positive and negative control cells were treated for $72 \mathrm{~h}$ with etoposide at the same concentrations of the extracts and DMSO at the highest concentration used in the test wells $(0.5 \%, \mathrm{v} / \mathrm{v})$, respectively. Two hours before the end of the incubation period, 20 $\mu \mathrm{L}$ of MTT ( $5 \mathrm{mg} / \mathrm{mL}$ in PBS, w/v) were added to each well and further incubated for $2 \mathrm{~h}$ at $37^{\circ} \mathrm{C}$. The optical density (OD) was measured on a Biotek Synergy 4 spectrophotometer at $590 \mathrm{~nm}$. Results were expressed in terms of cell viability (\%) and as half maximal inhibitory concentration $\left(\mathrm{IC}_{50}, \mu \mathrm{g} / \mathrm{mL}\right)$. The selectivity index (SI) of the extracts was determined using the equation $S I=$ $169 C_{T} / C_{N T}$, where $C_{T}$ and $C_{N T}$ correspond to the extract-induced cytotoxicity on tumor (e.g. HepG2) 170 and non-tumor cells (e.g. S17), respectively (Oh et al., 2011). 
171 2.8. Cellular proliferation analysis by the BrdU incorporation assay. The effect of the extracts on

172 HepG2 cells proliferation was evaluated by the BrdU incorporation assay. HepG2 cells were

173 incubated for $72 \mathrm{~h}$ with complete medium, DMSO $(0.5 \%, \mathrm{v} / \mathrm{v})$, or with $\mathrm{CTH}$ at the concentrations

174 of 2.31 or $4.62 \mu \mathrm{g} / \mathrm{mL}$, which were the $\mathrm{IC}_{50}$ or $2 \times \mathrm{IC}_{50}$ concentration previously determined by the

175 MTT assay. After a $1 \mathrm{~h}$ pulse with $10 \mu \mathrm{M}$ BrdU, cells were washed with phosphate buffer saline

176 (PBS), fixed in 4\% paraformaldehyde in PBS, and cytospins prepared. After incubation in 2M

$177 \mathrm{HCl}$ for $20 \mathrm{~min}$, cells were incubated with mouse anti-BrdU (1:10, v/v) and further incubated

178 with fluorescein-labeled rabbit anti-mouse antibody $(1: 100$, v/v). For nuclear staining,

179 Vectashield mounting medium for fluorescence with DAPI was used. Cells were observed in a

180 LEICA DM2000 microscope using a $200 \times$ magnification, and a semi-quantitative evaluation was

181 performed by counting a minimum of 500 cells per slide.

\section{2.9. Detection of apoptosis}

183 2.9.1. Flow cytometry apoptosis detection through Annexin V-FITC staining. Apoptotic cells were

184 identified and quantified by flow cytometry using the FITC-conjugated Annexin V/PI assay kit, 185 according to the manufacturer's instructions. Briefly, cells were treated for $72 \mathrm{~h}$ with complete 186 medium, DMSO $(0.5 \%, \mathrm{v} / \mathrm{v})$, or with $\mathrm{CTH}$ at the concentrations of $3.9,7.8$ and $15.6 \mu \mathrm{g} / \mathrm{mL}$.

187 Etoposide treated-cells at $\mathrm{IC}_{50}$ concentration $(1.85 \mu \mathrm{g} / \mathrm{mL})$ were used as positive control. HepG2 188 cells were washed with ice-cold PBS, resuspended in $100 \mu \mathrm{L}$ binding buffer, and stained with 5 $189 \mu \mathrm{L}$ of FITC-conjugated Annexin V $(10 \mathrm{mg} / \mathrm{mL})$ and $10 \mu \mathrm{L}$ of propidium iodide PI $(50 \mathrm{mg} / \mathrm{mL})$. 190 The cells were incubated for $15 \mathrm{~min}$ at RT in the dark and then $500 \mu \mathrm{L}$ of binding buffer was 191 added. Flow cytometry was performed using a FACS Calibur Flow Cytometer (Becton192 Dickinson, USA) and data acquisition and analysis were done with CellQuest Pro software. At 193 least $1 \times 10^{4}$ events were recorded for each sample and represented as dot plots. For analysis, 
194 HepG2 cells were gated separately according to their size and granularity on forward scatter vs. 195 side scatter plots. Apoptosis was evaluated on fluorescence channel 2 (for PI) vs. fluorescence 196 channel 1 (for Annexin) plots (Zhang et al., 1997; Abu Bakar et al. 2010).

197 2.9.2. DAPI staining. HepG2 cells were grown in 6-well plates at seeding densities of $5 \times 10^{5}$ 198 cells/well and treated for $72 \mathrm{~h}$ with $\mathrm{CTH}$ at 3.9, 7.8 and $15.6 \mu \mathrm{g} / \mathrm{mL}$. Cells incubated with culture 199 medium or with DMSO at the concentration of $0.5 \%(\mathrm{v} / \mathrm{v})$ were used as blank or negative control, 200 respectively. Etoposide treated-cells at $\mathrm{IC}_{50}$ concentration $(1.85 \mu \mathrm{g} / \mathrm{mL})$ were used as positive 201 control. Cells were then washed with PBS and incubated with DAPI ( $5 \mu \mathrm{g} / \mathrm{mL}$ in PBS) for 2 min 202 at RT. Fluorescence was visualized using a Leica DM LB (Leica Microsystems DI, Cambridge) 203 microscope, magnification $400 \times$. Images were acquired using a Leica DC 300 FX digital 204 camera. Cells under apoptosis were identified by marked condensation of chromatin and 205 cytoplasm (apoptotic cells), plasma membrane blebbing (apoptotic bodies), and intra- and 206 extracellular chromatin fragments (Murugan et al., 2010).

HepG2 cells were used to produce spheroids by modification of the hanging drop method (Keller, 1995). Single-cell suspensions $\left(1 \times 10^{4}\right.$ cells $\left./ \mathrm{mL}\right)$ were generated from trypsinized monolayers. Aggregate culture of HepG2 cells were generated by growth on non-adherent, bacterial-grade polystyrene Petri dishes. Cell suspension $(30 \mathrm{~mL})$ was then dispensed into 6 drops into the lid of

213 a Petri dish. Upon inversion of the lid, the hanging drops were held in place by surface tension 214 and cells accumulated at the free liquid-air interface. The Petri lids were placed in the dishes with 215 PBS and incubated for four days under standard conditions. 
216

217

218

219

220

221

222

223

224

225

226

227

228

229

230

231

232

233

234

235

236

237

\subsubsection{MCTS treatment with bioactive extract}

After four days, in each Petri dish, three of the six multicellular tumor spheroids (MCTS) were incubated with $\mathrm{CTH}$ at 20, 40 and $80 \mu \mathrm{g} / \mathrm{mL}$ for 24 and $48 \mathrm{~h}$. Incubation was carried out by replacing the medium with $30 \mu \mathrm{L}$ of fresh culture medium containing the extract. The remaining three MCTS were used as control; the cultured medium was replaced by fresh medium containing the same volume of DMSO. Images were captured at incubation time $0,24,48$ and 72 hours by means of an Olympus SZX7 microscope (using a $20 \times$ magnification) with a digital camera (Optica B3). Each experiment was done in triplicate.

\subsection{Compound isolation and elucidation. CTH (9 g) was fractionated by column} chromatography $(2.5 \times 18 \mathrm{~cm})$ over silica gel $\left(\mathrm{SiO}_{2}\right)$ using increasing amounts of ethyl acetate in hexane $(9: 1 ; 85: 15 ; 4: 1 ; 75: 25 ; 7: 3 ; 3: 2 ; 1: 1)$ and increasing amounts of methanol in ethyl acetate $(9: 1 ; 8: 1 ; 5: 1 ; 2: 1 ; 1: 1)$, methanol $(100 \%)$ and water $(100 \%)$ as eluents to give 57 fractions. Each fraction was analyzed by TLC and pooled together to afford 21 samples. These samples were tested for cytotoxic activity and selectivity and the active fraction 7 (21.6 mg) was chosen for characterization. Fraction 7 was re-fractionated over $\mathrm{SiO}_{2}$ eluted with hexane; hexane/EtOAc (8:2); hexane/EtOAc (7:3); hexane/EtOAc (6:4); hexane/EtOAc (5:5); hexane/EtOAc (4:6); EtOAc and $\mathrm{MeOH}$ to afford compound $\mathbf{1}(1.1 \mathrm{mg})$.

Compound 1. Oil. ${ }^{1} \mathrm{H}$ NMR (DMSO-d 6 , $\left.500 \mathrm{MHz}\right) \delta 8.50$ (1H, s, 4'-O프), 6.34 1H, br s, H-5'), $6.25\left(1 \mathrm{H}, \mathrm{d}, J=3.0 \mathrm{~Hz}, \mathrm{H}-3^{\prime}\right), 6.20(1 \mathrm{H}, \mathrm{d}, J=5.0 \mathrm{~Hz}, \mathrm{H}-14), 5.57$ (1H, d, $\left.J=5.0 \mathrm{~Hz}, \mathrm{H}-13\right)$, 4.29 (1H, s, H-6), 2.71 (2H, t, J= $7.5 \mathrm{~Hz}, \mathrm{H}-1), 2.16$ (2H, s, H-4), 2.07 (3H, s, 6'-C $\left.\underline{H}_{3}\right), 1.90-$ 1.20 (6H, m, H-8, H-9 and H-10), 1.79 (2H, m H-2), 1.31/1.28 (3H, s, H-20), 1.25 (3H, s, H-17), $1.24(3 \mathrm{H}, \mathrm{s}, \mathrm{H}-16), 1.23$ (3H, s, H-19), 0.83 (3H, s, H-18); ${ }^{13} \mathrm{C}$ NMR (DMSO-d, $\left.125 \mathrm{MHz}\right) \delta$ 
238149.4 (C-4'), 146.3 (C-1'), 143.9 (C-5), 140.1 (C-13), 126.2 (C-6'), 125.7 (C-14), 120.7 (C-2'),

239115.5 (C-12), 114.6 (C-3’), 112.4 (C-5’), 110.4 (C-6), 87.8 (C-15), 74.8 (C-3), 45.6 (C-4), 43.6

240 (C-11), 43.2 (C-7), 42.5 (C-8), 35.6 (C-10), 30.8 (C-2), 28.5 (C-17), 26.3 (C-18), 24.9 (C-20),

24122.6 (C-1), 21.9 (C-16), 19.9 (C-9), 19.6 (C-19), 15.9 (6'- $\left.\underline{\text { CH}}{ }_{3}\right) ;$ LRESIMS m/z $425[\mathrm{M}+\mathrm{H}]^{+}$.

242 Chemical shifts are reported in $\delta$ units (parts per million) and coupling constants $(J)$ in Hertz.

243 2.12. Statistical Analysis. Results were expressed as mean \pm standard error of the mean (SEM).

244 Analysis of variance (ANOVA) was assessed using the SPSS statistical package for Windows

245 (release 15.0, SPSS Inc.), and significance between means was analysed by the Tukey HSD test

$246(p<0.05)$. The $\mathrm{IC}_{50}$ values were calculated by sigmoidal fitting of the data by means of GraphPad

247 Prism v. 5.0 (GraphPad Software, Inc., La Jolla, CA). Pearson correlation coefficient (r) was also

248 calculated $(p<0.01)$ to assess the strength of the linear relationship between two variables.

\section{3. Results and discussion}

250 3.1. TPC and antioxidant activity. The results of total phenolic content and antioxidant activity

251 are summarized in Table 1. C. tamariscifolia was the species with the highest TPC, mainly in the 252 hexane, diethyl ether and ethyl acetate extracts, which presented TPC values higher than $100 \mathrm{mg}$ 253 GAE/g DW. C. usneoides diethyl ether extract also had a high TPC (122 mg GAE/g DW), 254 whereas $C$. humilis methanol extract had the lowest levels of phenolic content (4.78 mg GAE/g 255 DW). The highest RSA were observed with C. tamariscifolia ethyl acetate, diethyl ether and 256 hexane extracts which $\mathrm{IC}_{50}$ for $\mathrm{DPPH}\left(\mathrm{IC}_{50-\mathrm{DPPH}}\right)$ and for $\mathrm{ABTS} \bullet^{+}\left(\mathrm{IC}_{50-\mathrm{ABTS}}\right)$ ranged from 0.17 to $2570.63 \mathrm{mg} / \mathrm{mL}$ and from 0.26 to $0.52 \mathrm{mg} / \mathrm{mL}$, respectively. Similar results were obtained with $C$. 258 usneoides diethyl ether extract $\left(\mathrm{IC}_{50-\mathrm{DPPH}}=0.65 \mathrm{mg} / \mathrm{mL} ; \mathrm{IC}_{50-\mathrm{ABTS}}=0.60 \mathrm{mg} / \mathrm{mL}\right)$. The hexane and 
259 methanol extracts of $C$. humilis had the lowest scavenging activity $\left(\mathrm{IC}_{50}>10 \mathrm{mg} / \mathrm{mL}\right.$ for both 260 radicals).

261 Taken together, our results indicate that $C$. tamariscifolia contains phenolic compounds of

262 different polarities, which occur mainly in the less polar extracts. Distribution of phenolic 263 compounds through different solvents may vary greatly usually due to their amphipathic 264 properties and wide range of structures (Ivanova et al., 2005; Demiray et al., 2009). Though 265 commonly found in polar extracts such as methanol and water, phenolic compounds can also be 266 present in less polar extracts including hexane, diethyl ether and ethyl acetate (Li et al., 2007;

267 Maimoona et al., 2011). This may in fact explain the high levels of phenolic compounds in less 268 polar extracts of Cystoseira, since the sequential extraction procedure used began with solvents 269 of lower polarity (Li et al., 2007).

270 Phenolic compounds are described as strong antioxidants (Dai and Mumper, 2010). In this 271 work, a significant correlation was observed between TPC and RSA on DPPH $\left(r^{2}=0.868, p<0.01\right)$ 272 as well as TPC and RSA on ABTS $\left(r^{2}=0.921, p<0.01\right)$, suggesting that the antioxidant activity 273 observed might be due to the activity of phenolic compounds. Data on TPC and antioxidant

274 activity in macroalgae are scarce, but the Cystoseira genus generally has one of the highest total 275 phenolic levels and antioxidant activities among Phaeophyceae macroalgae, such as Fucus 276 serratus, Dictyota dichotoma, Bifurcaria bifurcata, Sargassum horneri and Alaria crassifolia 277 among others (Zubia et al., 2009; Airanthi et al., 2011). A few authors were able to relate the 278 elevated antioxidant activity with tocopherol-like compounds, such as tetraprenyltoluquinol 279 derivatives (Foti et al., 1994; Fisch et al. 2003). In addition, the high RSA obtained for 280 Cystoseira extracts suggests that these macroalgae are potential sources of novel antioxidants that 281 may help prevent oxidative stress and also an alternative to BHT and butyl-4-hydroxyanisole 282 (BHA), two synthetic antioxidants found to be toxic and carcinogenic in animal models (Ito et al., 283 1986; Safer and Al-Nughamish, 1999). 
284 Oxidative stress is considered to be one of the underlying causes of several chronic diseases,

285 including cancer, and is implicated in both cytotoxic and apoptotic mechanisms (Goswami and 286 Singh, 2006). The link between oxidative stress and cell death has been associated, for example, 287 with lipid peroxidation, a process of oxidative degradation of lipids in which free radicals 288 'remove' electrons from membrane lipids. These events damage lipid bilayers, and impair several 289 intra- and extra mitochondrial membrane transport systems, thus contributing to apoptosis. As a 290 result, antioxidant compounds from natural sources have attracted much attention due to their 291 ability to diminish oxidative stress. In fact, antioxidant compounds play an important role in 292 regulation of gene expression and protection of DNA, lipids and proteins from oxidative stress293 induced injury (Saura-Calixto, 2011). Because of this protective effect, it has been proposed that 294 antioxidants may inhibit apoptosis when cancer cells should undergo cell death (Zeisel 2004). 295 However, the opposite has also been shown, i.e. molecules with known antioxidant properties 296 have been described to also promote apoptosis (Moustapha et al., 2015). Therefore the chemical 297 structure of the antioxidant and its biological properties seemed to be essential to define the 298 outcome of a given therapy with compounds with antioxidant properties.

3.2. Cytotoxic activity and selectivity. Natural extracts are considered as promising sources of antitumoral compounds when they exhibit $\mathrm{IC}_{50}$ values lower than $30 \mu \mathrm{g} / \mathrm{mL}$ (Dos Santos et al., 2010). This was the case for the hexane (CTH) and diethyl ether extracts of $C$. tamariscifolia, with $\mathrm{IC}_{50}$ values of 2.31 and $6.83 \mu \mathrm{g} / \mathrm{mL}$, respectively (Table 2 ). In fact, in the 303 literature, C. tamariscifolia also stood out as a potential source of antiproliferative compounds among other Phaeophyceae species (Zubia et al., 2009; Khanavi et al. 2010).

Interestingly, $\mathrm{CTH}$ had an $\mathrm{IC}_{50}$ statistically similar to that of the pure chemotherapeutic drug etoposide $\left(\mathrm{IC}_{50}=1.85 \mu \mathrm{g} / \mathrm{mL}\right)$. This result indicates that $\mathrm{CTH}$ has cell growth inhibitory activity in

307 vitro comparable with etoposide, a potent anti-cancer compound that acts as a topoisomerase II 308 inhibitor (Scott and William, 2000). In fact, etoposide is one of the most potent drugs used in the 
309 treatment of several types of tumors, including testicular and ovarian cancer (Hande, 1998).

310 However, different success rates are described for the treatment of different types of cancer with

311 that compound. For example, Miao et al. (2003) reported the occurrence of resistant cell lines to

312 this compound. It is also noteworthy to mention that HepG2 cells are known to display greater

313 resistance to drugs and toxins comparing to other cells lines (Liu et al., 2010).

314 Since CTH had the highest cytotoxic activity towards HepG2 cells, this extract was

315 further evaluated in other human tumor cell lines, namely cervical (HeLa), neuroblastoma (SH-

316 SY5Y), gastric (AGS) and colorectal (HCT-15) carcinoma cells. Furthermore, CHT treatment

317 was also carried out in murine stromal S17 and human umbilical HUVEC cell lines, both non318 tumor cell lines, to determine the selectivity index (SI). As shown in Fig. 1, CTH had a strong

319 cytotoxic activity in all tumor cell lines tested, except HeLa cells. This effect was, however, more 320 pronounced towards HepG2 cells $\left(\mathrm{IC}_{50}=2.31 \mu \mathrm{g} / \mathrm{mL}, p<0.01 v s . \mathrm{S} 17\right.$ and HUVEC cells $)$. Samples 321 with SI values higher than 3 are deemed as highly selective (Mahavorasirikul et al., 2010). CTH 322 was therefore considered highly selective when comparing HepG2 and S17 cells (SI=5.5, Fig.1) 323 and especially against HUVEC cells $(\mathrm{SI}=12.6)$. Based on these results, $\mathrm{CTH}$ was further used to 324 study the mode of action associated with the cytotoxicity observed on HepG2 cells.

\subsection{Cytotoxicity mechanisms.}

\subsubsection{Cellular proliferation analysis by the BrdU incorporation assay.}

The BrdU incorporation assay was used in order to assess the effect of CTH on HepG2 cells proliferation. Results show that cells treated with $\mathrm{CTH}$ at concentrations of 2.31 or 4.62 $\mu \mathrm{g} / \mathrm{mL}$ incorporated less BrdU than control cells (treated with medium only or with $0.5 \%$ DMSO). In fact, the proliferation levels, expressed as the percentage of proliferating cells, underwent an almost 2-fold reduction, decreasing from $25.8 \%$ to $17.5 \%$ or $13.6 \%$ respectively 
332 after treatment with CHT at the concentration of $2.31 \mu \mathrm{g} / \mathrm{mL}$ or $4.62 \mu \mathrm{g} / \mathrm{mL}$ for $72 \mathrm{~h}(p<0.01$, 333 Fig. 2).

334 Although previous data on the inhibition of cell proliferation with macroalgae extracts is 335 very limited, it is interesting to observe that these results are consistent with studies from 336 Funahashi et al. (1999). According to those authors, rats fed with commercial feed supplemented 337 with wakame, an edible brown macroalga (Undaria pinnatifida) also belonging to the 338 Phaeophyceae, showed significantly lower BrdU indices in tumor mammary cells as compared to 339 a control group eating commercial feed alone. In fact, the authors showed that this phaeophyta 340 had a strong suppressive effect on rat mammary carcinogenesis without toxicity, possibly via 341 apoptosis induction.

342 3.3.2. Apoptosis-inducing activity. In order to verify whether CTH had apoptotic-inducing effect 343 on HepG2 cells, two methodologies were applied: (i) analysis of the externalization of 344 phosphatidylserine using flow cytometry (FITC-conjugated Annexin V/PI assay) and (ii) 345 visualization of morphological alterations following DAPI staining.

During apoptosis there is a loss of membrane asymmetry due to the translocation of 347 phosphatidylserine from the inner to the outer layer of the cell membrane (Koopman et al., 1994). 348 This translocation occurs before nuclear breakdown and DNA fragmentation (Koopman et al., 349 1994; Wu et al., 2005). Since Annexin V strongly binds to phosphatidylserine, Annexin V binding 350 to cells is considered to be a major marker of apoptosis (Zhang et al., 1997). The FITC351 conjugated annexin V/PI assay is a well-established method for the detection of living cells in 352 early and late apoptosis. The four different quadrants of flow cytometric data represent four 353 different states of cells. The lower left (LL) quadrant shows annexin-/PI-normal healthy cells. 354 The lower right (LR) and upper right (UR) represent early (annexin+/PI-) and late apoptotic 
355 (annexin $+/ \mathrm{PI}+$ ) cells, respectively. On the upper left quadrant (UL), necrotic (annexin-/PI+) cells 356 are displayed.

357 In this study, treatment of HepG2 cells with CTH resulted in a 2, 4 and 5-fold increase in 358 the number of apoptotic cells, at the concentrations of 3.9, 7.8 and $15.6 \mu \mathrm{g} / \mathrm{mL}$ respectively (Fig. 3). Necrotic cells were also observed, but mostly after incubation with the highest concentration tested $(15.6 \mu \mathrm{g} / \mathrm{mL} ; 7.12 \%)$. In fact, it has been described that treatment with cytotoxic drugs might stimulate apoptosis at lower doses and necrosis at higher doses (Zong and Thompson, 2006). Etoposide treated-cells (positive control) demonstrated $36.07 \%$ of apoptotic cells after

$36372 \mathrm{~h}$. These results indicate that apoptosis contributed significantly to the reduction in HepG2 364 viability when exposed to CTH. Moreover, the morphological alterations observed upon DAPI 365 staining confirmed the results of the FITC-conjugated Annexin V/PI assay. In fact, treated cells 366 exhibited noticeable morphological alterations typical of apoptosis, such as nuclear fragmentation 367 and chromatin condensation (Fig. 4). These morphological modifications were dose-dependent 368 and already visible after treatment with the lowest concentration tested $(3.9 \mu \mathrm{g} / \mathrm{mL})$.

Failure of apoptosis is a characteristic of the tumorigenic process. Thus, one strategy underlying anticancer drug development is the induction of the apoptotic machinery in cancer 371 cells. In fact, most cytotoxic compounds used for cancer treatment are apoptotic inducers 372 (Vecchione and Croce, 2010). On that note, recent research has shown strong evidence for anti373 proliferative, pro-apoptotic and growth-inhibiting properties of Phaeophyceae extracts in a 374 number of tumor models, including melanoma, lymphoma and lung cancer (Aisa et al., 2005;

375 Culioli et al., 2004; Dias et al., 2005). Taken together, these results strongly indicate that $C$. 376 tamariscifolia contains compounds that are able to induce apoptosis in a human hepatocarcinoma 377 cell line. 
378 3.4. Effect on MCTS. Anticancer drugs must penetrate into tumor cell masses to reach all cells at

379 adequate concentrations. According to the vast majority of literature reports, many treatments are 380 expected to lose efficacy in a three-dimensional (3D) pathophysiological environment, and 381 testing on in vitro spheroid tumors is often considered a useful tool for negative selection to 382 reduce animal testing or to evaluate drug candidates with enhanced tissue distribution and 383 efficacy (Hirschhaeuser et al., 2010).

384 The effect of the application of CTH on 3D MCTS was examined in detail by optical 385 microscopy. As shown in Fig. 5, MCTS presented a homogeneous size distribution in the 386 controls. Loss of spheroid integrity was observed after 24 and $48 \mathrm{~h}$ following application of the extract at a concentration of $20 \mu \mathrm{g} / \mathrm{mL}$. After incubation with $40 \mu \mathrm{g} / \mathrm{mL}$ of extract, this outcome was more evident and incubation with the hexane extract at $80 \mu \mathrm{g} / \mathrm{mL}$, total disaggregation of MCTS occurred.

Generally, tumor cell lines are more resistant to antineoplastic agents when the cells are grown as spheroids rather than as monolayer cultures. The resistance of MCTS to anticancer drugs appears to reflect both limited drug penetration into the inner regions of the 3D cell masses as well as acquired resistance at the multicellular level (Gong et al. 2015). Although in vivo, tumors are affected by other cell types such as fibroblasts monocultures of multicellular spheroids from human tumor cell lines have proven to be a prevailing tool in the study of the microenvironmental regulation of tumor cell physiology and therapeutic problems associated with metabolic and proliferative gradients in a 3D cellular context (Rodriguez-Enriquez et al., 2008).

398 The fact that the whole mass of tumor cells completely lost their adherence demonstrates that the compounds present in CTH have penetrated and may be effective in a multicellular tumor stage.

400 The observed results combined with the anti-proliferative data confirmed the potential of CTH as 401 a promising source of anticancer compounds. 
402

403

404

405

406

407

408

409

410

411

412

413

414

415

416

417

418

419

420

421

422

423

424

3.5. Compound isolation, structural elucidation and bioactivities. CTH was subjected to a bioguided fractionation, affording 21 fractions, which were tested for cytotoxicity at $20 \mu \mathrm{g} / \mathrm{mL}$ against HepG2 using the MTT assay (Fig. 6). Fractions 7, 9, 13 and 14 were those that strongly reduced the viability of HepG2 cells (Fig. 6, $p<0.001$ ). Among these, fraction 7 was the one combining a high effect on HepG2 cell viability and highest selectivity index comparing to S17 cells $(\mathrm{SI}=5.6)$. Thus, fraction 7 was further purified in order to isolate and identify its major compound.

Compound 1 (Fig. 7) was obtained as an epimeric mixture at C-3 and 4. The ${ }^{1} \mathrm{H}$ NMR spectrum (DMSO- $\left.d_{6}\right)$ showed two coupled aromatic hydrogen atoms at $\delta 6.34(\mathrm{br}, \mathrm{s})$ and $6.25(\mathrm{~d}$, $J=3.0 \mathrm{~Hz}$ ), assigned to $\mathrm{H}-5^{\prime}$ and $\mathrm{H}-3^{\prime}$, respectively. Two chemical shifts attributed to hydrogens linked to $\mathrm{sp}^{2}$ carbons were also observed at $\delta 4.29(\mathrm{~s}, \mathrm{H}-6), 5.57(\mathrm{~d}, J=5.0 \mathrm{~Hz}, \mathrm{H}-13)$ and 6.20 $(\mathrm{d}, J=5.0 \mathrm{~Hz}, \mathrm{H}-14)$ while six methyl groups were detected at $\delta 2.07\left(6{ }^{\prime}-\underline{\mathrm{H}}_{3}\right), 1.31 / 1.28(\mathrm{H}-20)$, $1.25(\mathrm{H}-17), 1.24(\mathrm{H}-16), 1.23(\mathrm{H}-19)$, and $0.83(\mathrm{H}-18)$. The occurrence of a chromane moiety in the molecule was proposed due the cross peaks at $\mathrm{d} 2.58(\mathrm{t}, J=7.5 \mathrm{~Hz})$ and $1.79(\mathrm{~m})$, assigned to $\mathrm{H}-1$ and $\mathrm{H}-2$, respectively, as observed in the COSY spectrum. The ${ }^{13} \mathrm{C}$ NMR data confirmed the structural similarity with a cystoketal derivative (Amico et al., 1984) mainly due to the signals attributed to carbons of aromatic ring C-1' to C-6' ( $\delta 112.4-149.4)$, to carbons of double bonds C-5 ( $\delta$ 143.9), C-6 ( $\delta 110.4), \mathrm{C}-13(\delta 140.1), \mathrm{C}-14(\delta 125.7)$ as well as to carbinolic carbons C-12 $(\delta 115.5), \mathrm{C}-15(\delta 87.8)$, and C-3 ( $\delta$ 75.8). LRESIMS spectrum showed the protonated molecular ion $[\mathrm{M}+\mathrm{H}]^{+}$at $\mathrm{m} / z$ 425, establishing the molecular formula $\mathrm{C}_{27} \mathrm{H}_{36} \mathrm{O}_{4}$. Data of the isolated compound was consistent with demethoxy cystoketal chromane (compound 1, Fig. 7), a meroditerpene previously isolated from C. amentacea (Valls et al., 1996), a species closely related to $C$. tamariscifolia. 
426 had an activity of $18.21 \%$ and $13.73 \%$ towards DPPH and ABTS radicals, respectively. These 427 results indicate that compound 1 was not responsible for the antioxidant activity detected in the 428 crude extract. In fact, the antioxidant activity is most likely a result of a synergistic effect 429 between different constituents of the crude extract as described by Palafox-Carlos et al. (2012). 430 Finally, compound 1 was tested towards HepG2 and S17 cells and was able to significantly 431 reduce the viability of $\mathrm{HepG} 2$ cells $\left(\mathrm{IC}_{50}=14.77 \mu \mathrm{g} / \mathrm{ml}\right)$ while maintaining a high selectivity 432 towards $\mathrm{S} 17\left(\mathrm{IC}_{50}=48.46 \mu \mathrm{g} / \mathrm{ml}, \mathrm{SI}=3.28\right)$. Meroditerpenoids consist of a polyprenyl chain 433 attached to hydroquinone ring moiety. In those, plastoquinones, chromanols and chromenes are 434 included and they are found in animals, plants, and microorganisms (Luckner, 1984). In the 435 marine environment, these compounds are especially abundant in brown algae such as species 436 belonging to the Cystoseira and Sargassum genera (Blunt et al. 2014). In addition, various 437 diterpenes have been identified as bioactive in C. crinita (Fisch et al., 2003), C. myrica (Ayyad et 438 al., 2003) and C. usneoides (Urones et al., 1992). Furthermore, brown algal-derived chromene metabolites have shown to exhibit anticancer and antimutagenic activities as well as inhibitory 440 activities against various enzymes (Stonik, Makarieva, and Dimitrenok 1992; Yamamoto et al. 441 1999).

442 To date, no bioactivities of this compound have been reported previously. To the authors' 443 knowledge, this is the first time that demethoxy cystoketal chromane has been isolated from $C$. 444 tamariscifolia and described as antiproliferative in HepG2 cells. In the future this molecule could 445 be structurally optimized in order to increase pharmacokinetic and pharmacodynamic parameters 446 among others. 
448 In this work, three Cystoseira species were evaluated for their potential as sources of antioxidant

449 and cytotoxic compounds. C. tamariscifolia had a strong antioxidant potential and a high content 450 of phenolic compounds as well as a potent selective cytotoxic effect against hepatocellular 451 carcinoma cells, especially its hexane extract (CTH). Moreover, CTH reduced cell proliferation 452 and inhibited cell growth through apoptosis induction. This extract also had promising results in a 453 3D MCTS model, promoting the disaggregation of the mass of tumor cells after $24 \mathrm{~h}$. Using 454 bioactivity-guided fractionation procedures, it was possible to isolate and identify demethoxy 455 cystoketal chromane as the major compound of $\mathrm{CTH}$, and its selective cytotoxicity towards the 456 recalcitrant HepG2 cell line was confirmed. It is also important to mention that this is the first 457 description of demethoxy cystoketal chromane (1) in C. tamariscifolia, which was fully 458 characterized as demethoxy cystoketal by analysis of MS and NMR spectral data. Overall, 459 Cystoseira can be considered a valuable source of bioactive secondary metabolites and a 460 promising source of health products.

\section{Acknowledgements}

462 The authors would like to thank Jesus Garcia (IRB - Institute for Research in Biomedicine) for 463 the realization of the spectra.

\section{References}

465 Abu Bakar M.F., Mohamad M., Rahmat A., Burr S.A., Fry, J.R. Cytotoxicity, cell cycle arrest, 466 and apoptosis in breast cancer cell lines exposed to an extract of the seed kernel of Mangifera pajang (bambangan). Food and Chemical Toxicology, 2010; 48: 1688-1697. 
468 Airanthi M.K., Hosokawa M., Miyashita K. Comparative antioxidant activity of edible Japanese 469 brown seaweeds. Journal of Food Science, 2011; 76: C104-111.

470 Aisa Y., Miyakawa Y., Nakazato T., Shibata H., Saito K., Ikeda Y., Kizaki M. Fucoidan induces 471 apoptosis of human HS-sultan cells accompanied by activation of caspase-3 and downregulation of ERK pathways. American Journal of Hematology, 2005; 78: 7-14.

Amico V. Marine brown algae of family Cystoseiraceae: Chemistry and chemotaxonomy. $474 \quad$ Phytochemistry, 1995; 39: 1257-1279.

475 Amico V., Cunsolo F., Oriente G., Piatelli M., Ruberto G. Cystoketal, a new metabolite from the 476 Brown alga Cystoseira balearica. Journal of Natural Products, 1984; 47: 947-952.

Ayyad S.E., Abdel-Halim O.B., Shier W.T., Hoye T.R. Cytotoxic hydroazulene diterpenes from 478 the brown alga Cystoseira myrica. Zeitschrift für Naturforschung C, 2003; 58: 33 - 38.

479 Balboa E.M., Conde E., Moure A., Falqué E., Domínguez H. In vitro antioxidant properties of $480 \quad$ crude extracts and compounds from brown algae. Food Chemistry, 2013; 138: 1764-85.

481 Blunt J.W., Copp B.R., Keyzers R.A., Munro M.H.G., Prinsep M.R. Marine natural products. $482 \quad$ Natural Products Reports, 2014; 31: 160-258.

483 Brand-Williams W., Cuvelier M., Berset C. Use of a free radical method to evaluate antioxidant $484 \quad$ activity. LWT - Food Science and Technology, 1995; 28: 25-30.

485 Caamal-Fuentes E., Moo-Puc R., Freile-Pelegrín Y., Robledo D. Cytotoxic and antiproliferative 486 constituents from Dictyota ciliolata, Padina sanctae-crucis and Turbinaria tricostata. 487 Pharmaceutical Biology, 2014; 27: 1-5.

488 Culioli G., Ortalo-Magne A., Daoudi M., Thomas-Guyon H., Valls R., Piovetti L. 489 Trihydroxylated linear diterpenes from the brown alga Bifurcaria bifurcata. Phytochemistry, $490 \quad 2004 ; 65: 2063-2069$.

491 Custódio L., Soares F., Pereira H., Barreira L., Vizetto-Duarte C., Rodrigues M.J., Rauter A.P., 492 Alberício F., Varela J. Fatty acid composition and biological activities of Isochrysis galbana T- 
493 ISO, Tetraselmis sp. and Scenedesmus sp.: possible application in the pharmaceutical and 494 functional food industries. Journal of Applied Phycology, 2013; 26: 151-161.

495 Dai J., Mumper R.J. Plant phenolics: extraction, analysis and their antioxidant and anticancer 496 properties. Molecules, 2010; 15: 7313-7352.

497 Demiray S., Pintado M.E., Castro P.M.L. Evaluation of phenolic profiles and antioxidant 498 activities of Turkish medicinal plants: Tilia argentea, Crataegi folium leaves and Polygonum 499 bistorta roots. World Academy of Science, Engineering \& Technology, 2009; 3: 270-275.

500 Dias P.F., Siqueira J.M. Jr, Vendruscolo L.F., de Jesus Neiva T., Gagliardi A.R., Maraschin M., 501 Ribeiro-do-Valle R.M. Antiangiogenic and antitumoral properties of a polysaccharide isolated 502 from the seaweed Sargassum stenophyllum. Cancer Chemotherapy and Pharmacology, 2005; 56: 436-446.

Dos Santos J.H., Oliveira D., De C.D., Pinto J., Campos V., Mourão A., Pessoa C, De M.M., Costa L.L. Evaluation of native and exotic Brazilian plants for anticancer activity. Journal of Natural Medicines, 2010; 64, 231-238.

Fisch K.M., Böhm V., Wright A.D., König G.M. Antioxidative meroterpenoids from the brown alga Cystoseira crinita. Journal of Natural Products, 2003; 66: 968-975.

Foti M., Piattelli M., Amico V., Ruberto G. Antioxidant activity of phenolic meroditerpenoids 510 from marine algae. Journal of Photochemistry and Photobiology B: Biology, 1994; 26: 159$511 \quad 164$.

512 Funahashi H., Imai T., Tanaka Y., Tsukamura K., Hayakawa Y., Kikumori T., Mase T., Itoh T., 513 Nishikawa M., Hayashi H., Shibata A., Hibi Y., Takahashi M., Narita T. Wakame seaweed 514 suppresses the proliferation of 7,12-dimethylbenz(a)-anthracene-induced mammary tumors in 515 rats. Japanese Journal of Cancer Research, 1999; 90: 922-927. 
516 Gong X., Lin C., Cheng J., Su J., Zhao H., Liu T., Wen X., Zhao P. Generation of Multicellular

517 Tumor Spheroids with Microwell-Based Agarose Scaffolds for Drug Testing. PLoS One. 2015; $518 \quad 10(6): \mathrm{e} 0130348$.

519 Goswami P.C., Singh K.K. Oxidative stress and multistage carcinogenesis. In: oxidative stress, 520 disease and cancer. Singh K. editor. Imperial College Press, London, 2006; pp 705-731.

521 Gouveia V.L.M., Seca A.M.L., Barreto M.C., Neto A.I., Kijjoa A., Silva A.M.S. Cytotoxic 522 meroterpenoids from the macroalga Cystoseira abies-marina. Phytochemistry Letters, 2013; 6: $523 \quad 593-597$.

524 Guiry M.D., Guiry G.M. Algae Base. World-wide electronic publication, National University of 525 Ireland, Galway, 2015; http://www.algaebase.org (searched on 14.01.15).

526 Hadj Ammar H., Lajili S., Ben Said R., Le Cerf D., Bouraoui A., Majdoub H. Physico-chemical 527 characterization and pharmacological evaluation of sulfated polysaccharides from three 528 species of Mediterranean brown algae of the genus Cystoseira. Daru, 2015; 23:1.

529 Hande K.R. Etoposide: four decades of development of a topoisomerase II inhibitor. European $530 \quad$ Journal of Cancer, 1998; 34: 1514-1521.

531 Heffernan N., Brunton N.P., FitzGerald R.J., Smyth T.J. Profiling of the molecular weight and 532 structural isomer abundance of macroalgae-derived phlorotannins. Marine Drugs, 2015; 13: $533 \quad 509-528$.

534 Hirschhaeuser F., Menne H., Dittfeld C., West J., Mueller-Klieser W., Kunz-Schughart L.A. 535 Multicellular tumor spheroids: an underestimated tool is catching up again. Journal of 536 Biotechnology, 2010; 148: 3-15.

537 Ito N., Hirose M., Fukushima H., Tsuda T., Shirai T., Tatenatsu, M. Studies on antioxidants: their 538 carcinogenic and modifying effects on chemical carcinogens. Food and Chemical Toxycology, $539 \quad$ 1986; 24: 1071-1092. 
540 Ivanova D., Gerova D., Chervenkov T., Yankova T. 2005. Polyphenols and antioxidant capacity 541 of Bulgarian medicinal plants. Journal of Ethnopharmacology, 2005; 97: 145-150.

542 Khanavi M., Gheidarloo R., Sadati N., Ardekani M.R.S., Nabavi S.M.B., Tavajohi S., Ostad S.N. 543 Cytotoxicity of fucosterol containing fraction of marine algae against breast and colon $544 \quad$ carcinoma cell line. Pharmacognosy Magazine, 2012; 8: 60-64.

545 Koopman G., Reutelingsperger C.P., Kuijten G.A., Keehnen R.M., Pals S.T., van Oers M.H. 546 Annexin $\mathrm{V}$ for flow cytometric detection of phosphatidylserine expression on B cells $547 \quad$ undergoing apoptosis. Blood, 1994; 84: 1415-1420.

548 Kurt O., Ozdal-Kurt F., Tuğlu M., Akçora C. The cytotoxic, neurotoxic, apoptotic and 549 antiproliferative activities of extracts of some marine algae on the MCF-7 cell line. Biotechnic $550 \quad \&$ Histochemistry, 2014; 28: 1-9.

551 Li H.-B., Cheng K.-W., Wong C.-C., Fan K.-W., Chen F., Jiang Y. Evaluation of antioxidant 552 capacity and total phenolic content of different fractions of selected microalgae. Food $553 \quad$ Chemistry, 2007; 102: 771-776.

554 Liu Y., Zhao C., Li H., Yu M., Gao J., Wang L., Zhai Y. Cytotoxicity and apoptosis induced by a 555 new podophyllotoxin glucoside in human hepatoma (HepG2) cells. Canadian Journal of $556 \quad$ Physiology and Pharmacology, 2010; 88: 472-9.

557 Mahavorasirikul W., Viyanant V., Chaijoroenkul W., Itharat A., Na-Bangchang K. Cytotoxic 558 activity of Thai medicinal plants against human cholangiocarcinoma, laryngeal and 559 hepatocarcinoma cells in vitro. BMC Complementary and Alternative Medicine, 2010; 10: 1-8.

560 Maimoona A., Naeem I., Saddiqe Z., Ali N. Analysis of total flavonoids and phenolics in 561 different fractions of bark and needle extracts of Pinus roxburghiiand Pinus wallichiana. 562 Journal of Medicinal Plants Research, 2011; 5: 5216-5220. 
563 Mhadhebi L., Laroche-Clary A., Robert J., Bouraoui A. Antioxidant, anti-inflammatory, and 564 antiproliferative activities of organic fractions from the Mediterranean brown seaweed 565 Cystoseira sedoides. Canadian Journal of Physiology and Pharmacology, 2011, 89:911-921.

566 Miao Z.H., Tang T., Zhang Y.X., Zhang J.S., Ding J. Cytotoxicity, apoptosis induction and 567 downregulation of MDR-1 expression by the anti-topoisomerase II agent, salvicine, in 568 multidrug-resistant tumor cells. International Journal of Cancer, 2003; 106: 108-115.

569 Montero L., Herrero M., Ibáñez E., Cifuentes A. Separation and characterization of phlorotannins 570 from brown algae Cystoseira abies-marina by comprehensive two-dimensional liquid 571 chromatography. Electrophoresis, 2014; 35: 1644-1651.

572 Moreno P., Petkov G., Ramazanov Z., Garsia G. Lipids, fatty-acids and sterols of Cystoseira 573 abies-marina. Botanica Marina, 1998; 41:375-378.

574 Moreno S., Scheyer T., Romano C.S., Vojnov A.A. Antioxidant and antimicrobial activities of 575 rosemary extracts linked to their polyphenol composition. Free Radical Research, 2006; 40: $576 \quad 223-231$.

577 Mosmann T. Rapid colorimetric assay for cellular growth and survival: Application to 578 proliferation and cytotoxicity assays. Journal of Immunological Methods, 1983; 65: 55-63.

579 Murugan R.S., Priyadarsini R.V., Ramalingam K., Hara Y., Karunagaran D., Nagini S. Intrinsic 580 apoptosis and NF- $\mathrm{KB}$ signaling are potential molecular targets for chemoprevention by black 581 tea polyphenols in HepG2 cells in vitro and in a rat hepatocarcinogenesis model in vivo. Food $582 \quad$ and Chemical Toxicology, 2010; 48: 3281-3287.

583 Oh S.H., Ahn J., Kang D.H., Lee H.Y. The effect of ultrasonificated extracts of Spirulina maxima 584 on the anticancer activity. Marine Biotechnology, 2011; 13: 205-214.

585 Palafox-Carlos H., Gil-Chávez J., Sotelo-Mundo R.R., Namiesnik J., Gorinstein S., González586 Aguilar G.A. Antioxidant interactions between major phenolic compounds found in 
587 'Ataulfo’Mango pulp: chlorogenic, gallic, protocatechuic and vanillic acids. Molecules, 2012; $588 \quad 17: 12657-12664$.

589 Re R., Pellegrini N., Proteggente A., Pannala A., Yang M., Rice-Evans C. Antioxidant activity 590 applying an improved ABTS radical cation decolorization assay. Free Radical Biology and $591 \quad$ Medicine, 1999; 26: 1231-1237.

592 Rodriguez-Enriquez S., Gallardo-Perez J.C., Aviles-Salas A., Marin-Hernandez A., Carreno593 Fuentes L., Maldonado-Lagunas V., Moreno-Sanchez R. Energy metabolism transition in 594 multi-cellular human tumor spheroids. Journal of Cellular Physiology, 2008; 216: 189-197.

595 Safer A.M., Al-Nughamish A.J. Hepatotoxicity induced by the antioxidant food additive 596 butylated hydroxytoluene (BHT) in rats: an electron microscopical study. Histolology and $597 \quad$ Histopathology, 1999; 14: 391-406.

598 Sathya R., Kanaga N., Sankar P., Jeeva S. Antioxidant properties of phlorotannins from brown 599 seaweed Cystoseira trinodis (Forsskål) C. Agardh. Arabian Journal of Chemistry. 2013; 600 doi:10.1016/j.arabjc.2013.09.039.

601 Saura-Calixto F. Dietary fiber as a carrier of dietary antioxidants: an essential physiological 602 function. Journal of Agricultural and Food Chemistry, 2011; 59: 43-49.

603 Scott H.K., William C.E. Induction of apoptosis by cancer chemotherapy. Experimental Cell $604 \quad$ Research, 2000; 256: 42-49.

605 Smit A.J. Medicinal and pharmaceutical uses of seaweed natural products: A review. Journal of 606 Applied Phycology, 2004; 16: 245-262.

607 Urones J.G., Basabe P., Marcos I.S., Pineda J., Lithgow A.M., Moro R.F., Palma F.M.S.B.,, 608 Araújo M.E.M., Gravalos M.D.G. Meroterpenes from Cystoseira usneoides. Phytochemistry, $609 \quad 1992 ; 31: 179-182$. 
610 Valls R., Mesguiche V., Piovetti L., Prost M., Peiffer G. Meroditerpenes from the brown alga 611 Cystoseira amentacea var. stricta collected off the French mediterranean coast. $612 \quad$ Phytochemistry, 1996; 41: 1367-1371.

613 Valls R., Piovetti L. The chemistry of the Cystoseiraceae (Fucales, Pheophyceae): 614 chemotaxonomic relationships. Biochemical Systematics and Ecology, 1995; 23: 723-745.

615 Vecchione A., Croce, C.M. Apoptomirs: small molecules have gained the license to kill. $616 \quad$ Endocrine-Related Cancer, 2010; 17: F37-50.

617 Velioglu Y.S., Mazza G., Gao L., Oomah B.D. Antioxidant activity and total phenolics in selected 618 fruits, vegetables and grain products. Journal of Agricultural and Food Chemistry, 1998; 46: $619 \quad 4113-4117$.

620 Wong R.S. Apoptosis in cancer: from pathogenesis to treatment. Journal of Experimental and 621 Clinical Cancer Research, 2011; 30:87.

622 Wu S.J., Ng L.T., Lin C.C. Cinnamaldehyde-induced apoptosis in human PLC/PRF/5 cells 623 through activation of the proapoptotic Bcl-2 family proteins and MAPK pathway. Life $624 \quad$ Sciences, 2005; 77: 938-951.

625 Yu B.P. Cellular defenses against damage from reactive oxygen species. Physiological Reviews, $626 \quad 1994 ; 74: 139-162$.

627 Zhang G., Gurtu V., Kain S.R., Yan G. Early detection of apoptosis using a fluorescent conjugate 628 of Annexin V. Biotechniques, 1997; 23: 525-531.

629 Zong W.X. and Thompson C.B. Necrotic death as a cell fate. Genes and Development, 2006; $630 \quad 20: 1-15$.

631 Zubia M., Fabre M.S., Kerjean V., Lann K.L., Stiger-Pouvreau V., Fauchon M., Deslandes E. 632 Antioxidant and antitumoural activities of some Phaeophyta from Brittany coasts. Food 633 Chemistry, 2009; 116: 693-701. 
634 Tables

635 Table 1 Total phenolic content (TPC, mg GAE/g DW), and radical scavenging activity (RSA) on 636 DDPH and ABTS radicals ( $\left.\mathrm{IC}_{50}, \mathrm{mg} / \mathrm{mL}\right)$ of organic extracts of different species of Cystoseira.

\begin{tabular}{|c|c|c|c|c|}
\hline $\begin{array}{l}\text { Species } \\
\text { /compound }\end{array}$ & Extract & $\begin{array}{c}\text { TPC (mg GAE/g } \\
\text { DW) }\end{array}$ & $\mathrm{IC}_{50-\mathrm{DPPH}}(\mathrm{mg} / \mathrm{mL})$ & $\mathrm{IC}_{50 \text {-ABTS }}(\mathrm{mg} / \mathrm{mL})$ \\
\hline \multirow[t]{4}{*}{ C. humilis } & Hexane & $24.42 \pm 0.46^{\mathrm{e}}$ & $>10$ & $>10$ \\
\hline & Diethyl ether & $20.34 \pm 0.68^{\mathrm{e}}$ & $8.28 \pm 0.13^{\mathrm{d}}$ & $8.85 \pm 0.23^{\mathrm{d}}$ \\
\hline & Ethyl acetate & $32.06 \pm 0.72^{\mathrm{d}}$ & $5.04 \pm 0.13^{\mathrm{c}}$ & $9.25 \pm 0.43^{\mathrm{d}}$ \\
\hline & Methanol & $4.78 \pm 0.80^{\mathrm{f}}$ & $>10$ & $>10$ \\
\hline \multirow[t]{4}{*}{ C. tamariscifolia } & Hexane & $113.13 \pm 2.31^{\mathrm{b}}$ & $0.63 \pm 0.01^{\mathrm{a}}$ & $0.52 \pm 0.02^{\mathrm{a}}$ \\
\hline & Diethyl ether & $116.61 \pm 2.44^{\mathrm{b}}$ & $0.30 \pm 0.00^{\mathrm{a}}$ & $0.47 \pm 0.02^{\mathrm{a}}$ \\
\hline & Ethyl acetate & $165.28 \pm 1.92^{\mathrm{a}}$ & $0.17 \pm 0.00^{\mathrm{a}}$ & $0.25 \pm 0.01^{\mathrm{a}}$ \\
\hline & Methanol & $45.04 \pm 2.28^{\mathrm{d}}$ & $1.08 \pm 0.06^{\mathrm{b}}$ & $2.93 \pm 0.67^{b}$ \\
\hline \multirow[t]{4}{*}{ C. usneoides } & Hexane & $75.56 \pm 0.21^{\mathrm{c}}$ & $4.37 \pm 0.03^{c}$ & $5.54 \pm 0.06^{\mathrm{c}}$ \\
\hline & Diethyl ether & $122.30 \pm 0.81^{\mathrm{b}}$ & $0.65 \pm 0.01^{\mathrm{a}}$ & $0.60 \pm 0.01^{\mathrm{a}}$ \\
\hline & Ethyl acetate & $17.76 \pm 0.78^{\mathrm{e}}$ & $7.37 \pm 0.76^{\mathrm{d}}$ & $>10$ \\
\hline & Methanol & $17.03 \pm 0.70^{\mathrm{e}}$ & $7.16 \pm 0.01^{\mathrm{d}}$ & $>10$ \\
\hline BHT* & & n.a. & $0.07 \pm 0.01$ & $0.11 \pm 0.00$ \\
\hline
\end{tabular}

638 Different letters in the same row indicate significant differences by Duncan's New Multiple 639 Range Test at $p<0.05$. *positive control, $1 \mathrm{mg} / \mathrm{mL}$; n.a. not applicable. 
640 Table 2 In vitro cytotoxic activity, expressed as $\mathrm{IC}_{50}$ values $(\mu \mathrm{g} / \mathrm{mL})$ of organic extracts of 641 different species of Cystoseira and etoposide on a human hepatocarcinoma cell line (HepG2).

\begin{tabular}{|c|c|c|c|c|}
\hline Extracts & C. humilis & C. tamariscifolia & C. usneoides & Etoposide \\
\hline Hexane & $>125$ & $2.31 \pm 0.08^{\mathrm{a}}$ & $31.4 \pm 3.22^{\mathrm{b}}$ & \multirow{4}{*}{$1.85 \pm 0.12^{\mathrm{a}}$} \\
\hline Diethyl ether & $>125$ & $6.83 \pm 0.01^{\mathrm{a}}$ & $52.0 \pm 3.19^{b}$ & \\
\hline Ethyl acetate & $>125$ & $44.2 \pm 1.41^{\mathrm{b}}$ & $>125$ & \\
\hline Methanol & $>125$ & $>125$ & $>125$ & \\
\hline
\end{tabular}




\section{Figures}
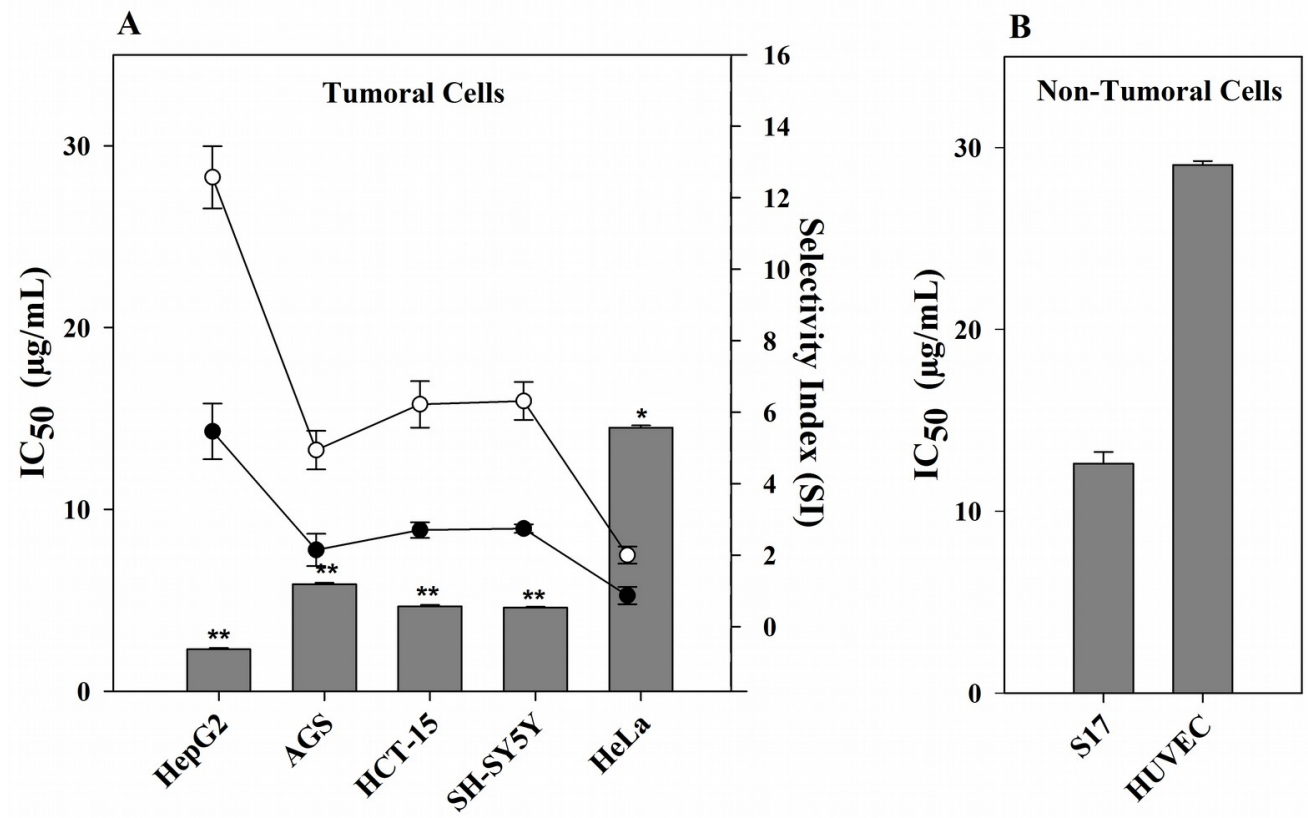

646 Figure 1 Effect of $\mathrm{CTH}$ on the viability of different cell lines. (A) $\mathrm{IC}_{50}$ values of $\mathrm{CTH}$ on tumor 647 and non-tumor cells (bars). Selectivity (scatter lines) was calculated using $\mathrm{IC}_{50}$ values of the non648 tumor cell line S17 (•) or HUVEC ( $)$ ) vs. the tumor cell lines. (B) $\mathrm{IC}_{50}$ value of CTH on non649 tumor cell lines. Results are expressed as mean \pm SEM of data obtained from six independent 650 experiments, ${ }^{*} p<0.05, * * p<0.01 v s$. HUVEC cells. 

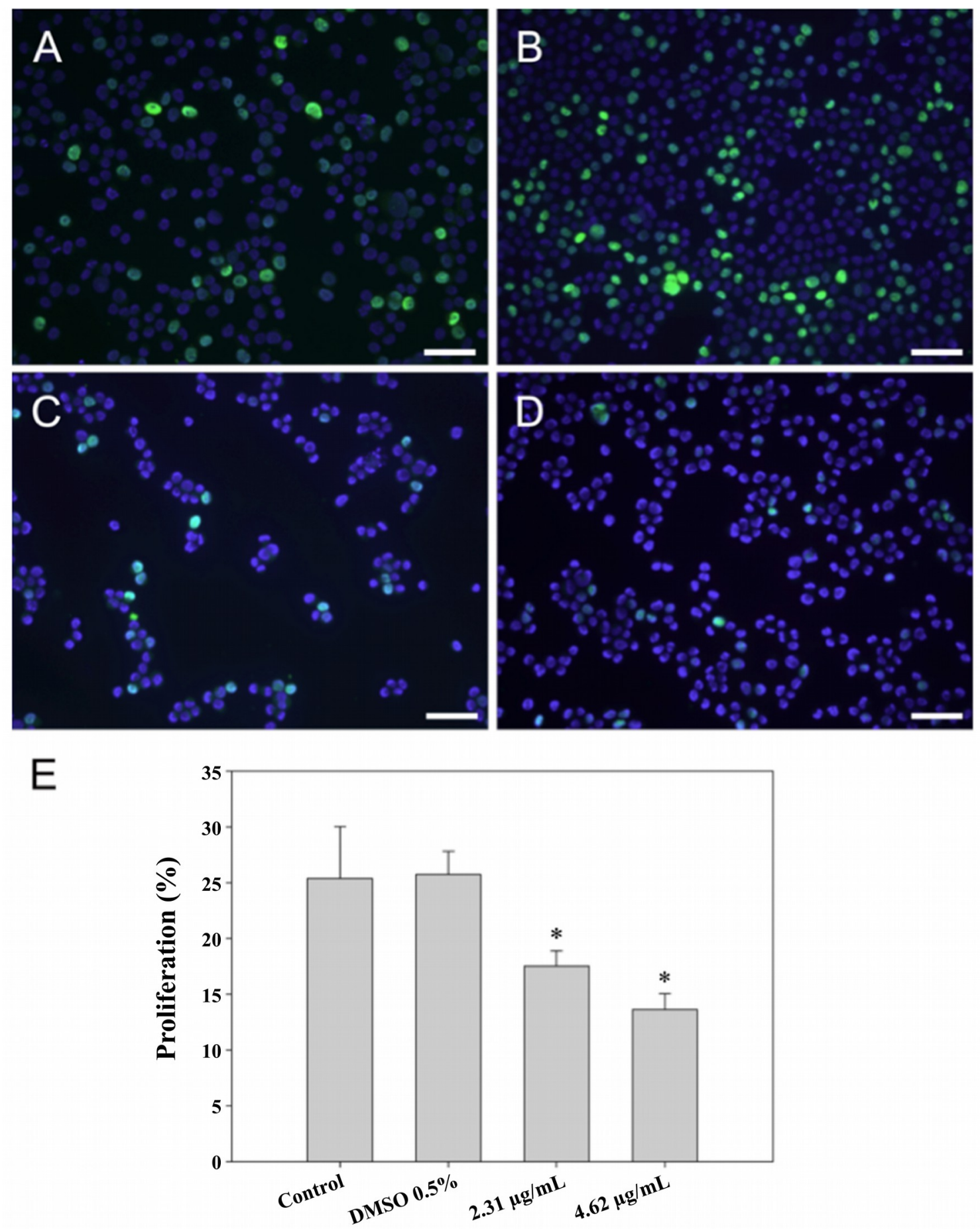

651 Figure 2 BrdU incorporation (stained in green) with nuclei labelled with DAPI (stained in blue).

652 HepG2 cells $(200 \times$ magnification) were treated for $72 \mathrm{~h}$ with complete medium alone (A), $0.5 \%$ 653 DMSO (B), or CTH at concentrations of 2.31 (C) or $4.62 \mu \mathrm{g} / \mathrm{ml}$ (D). Semi-quantitative analysis 654 of BrdU incorporation was carried out by counting a minimum of 500 cells per treatment in each 655 independent experiment $(\mathrm{E})$. Results are expressed as the mean $\pm \mathrm{SEM}$ of three independent 656 experiments, ${ }^{*} p<0.05$ vs. DMSO 0.5\%. Scale bar $=100 \mu \mathrm{m}$. 

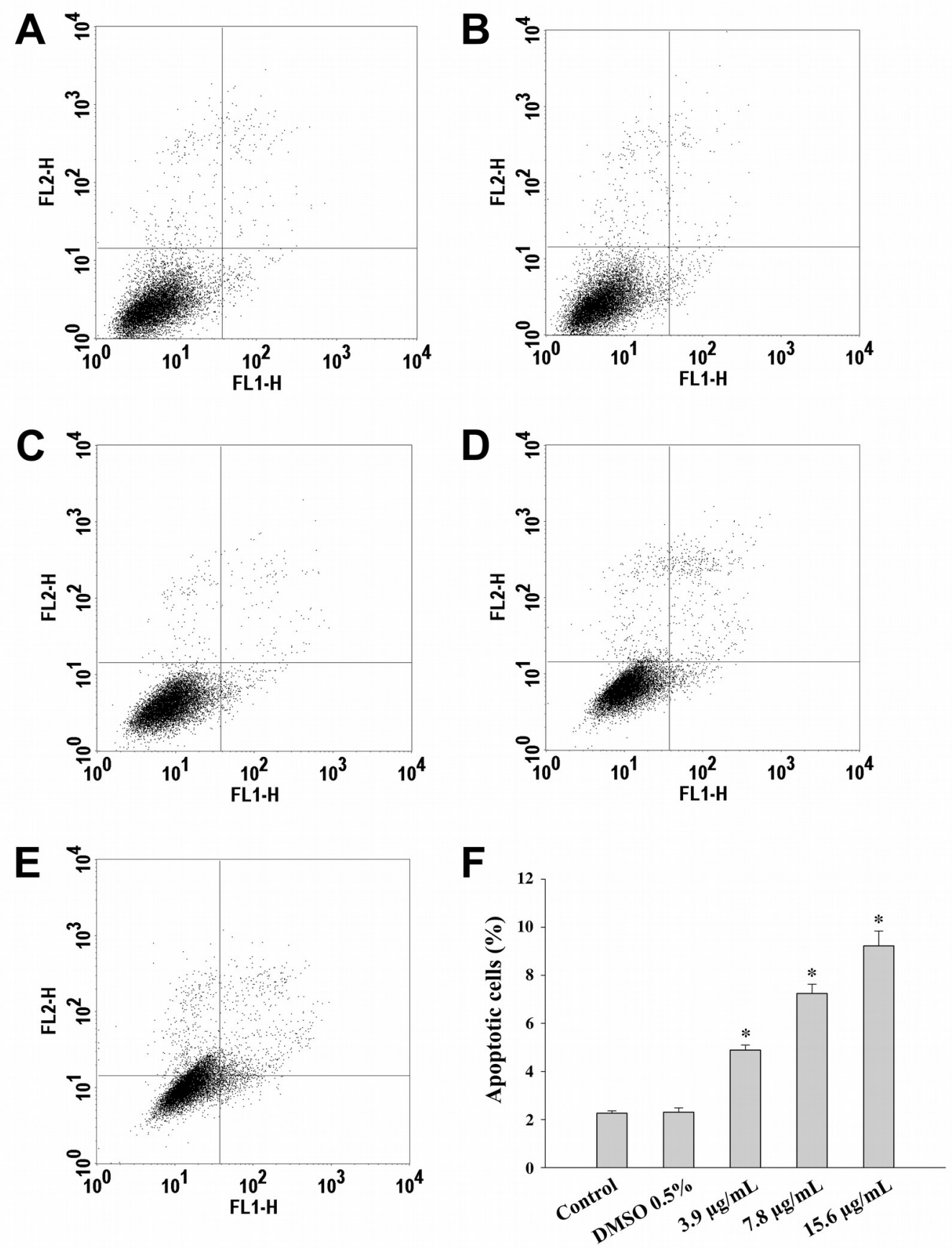

657 Figure 3 Incubation of HepG2 cells with CTH promotes apoptosis. Hepatocytes were treated with 658 medium alone as blank (A), DMSO 0.5\% (B, control), or CTH at concentrations of 3.9 (C), 7.8 659 (D) or $15.6 \mu \mathrm{g} / \mathrm{mL}$ (E) for 72h. Hepatocytes were then stained with PI/Annexin V-FITC and 660 analyzed by flow cytometry. (F) Quantitative analysis of apoptotic cells. Solid bars and errors 661 represent the mean \pm SEM, respectively $(n=6),{ }^{*} p<0.01 v s$. DMSO $0.5 \%$. 

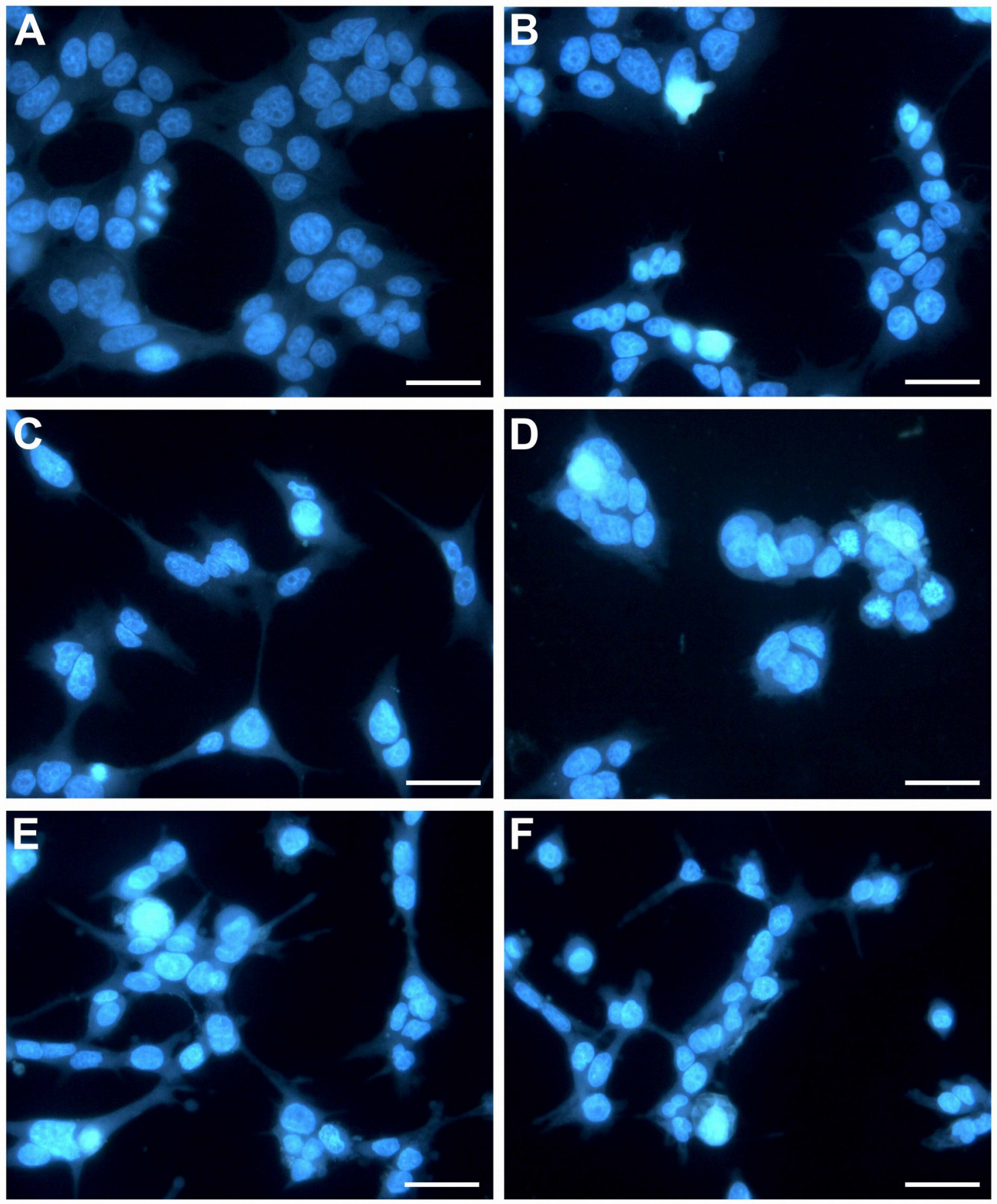

662 Figure 4 HepG2 cells exposed to CTH showing apoptotic features. Representative images (400× 663 magnification) in which hepatocyte nuclei are stained with DAPI (in blue) are shown. 664 Hepatocytes were treated with medium alone as blank (A), DMSO 0.5\% (B, control), or CTH at 665 concentrations of 3.9 (C), 7.8 (D), $15.6 \mu \mathrm{g} / \mathrm{mL}$ (E) or $1.85 \mu \mathrm{g} / \mathrm{mL}$ etoposide (F) as a positive 666 control for $72 \mathrm{~h}$. Scale bar $=50 \mu \mathrm{m}$. 
$24 \mathrm{~h}$
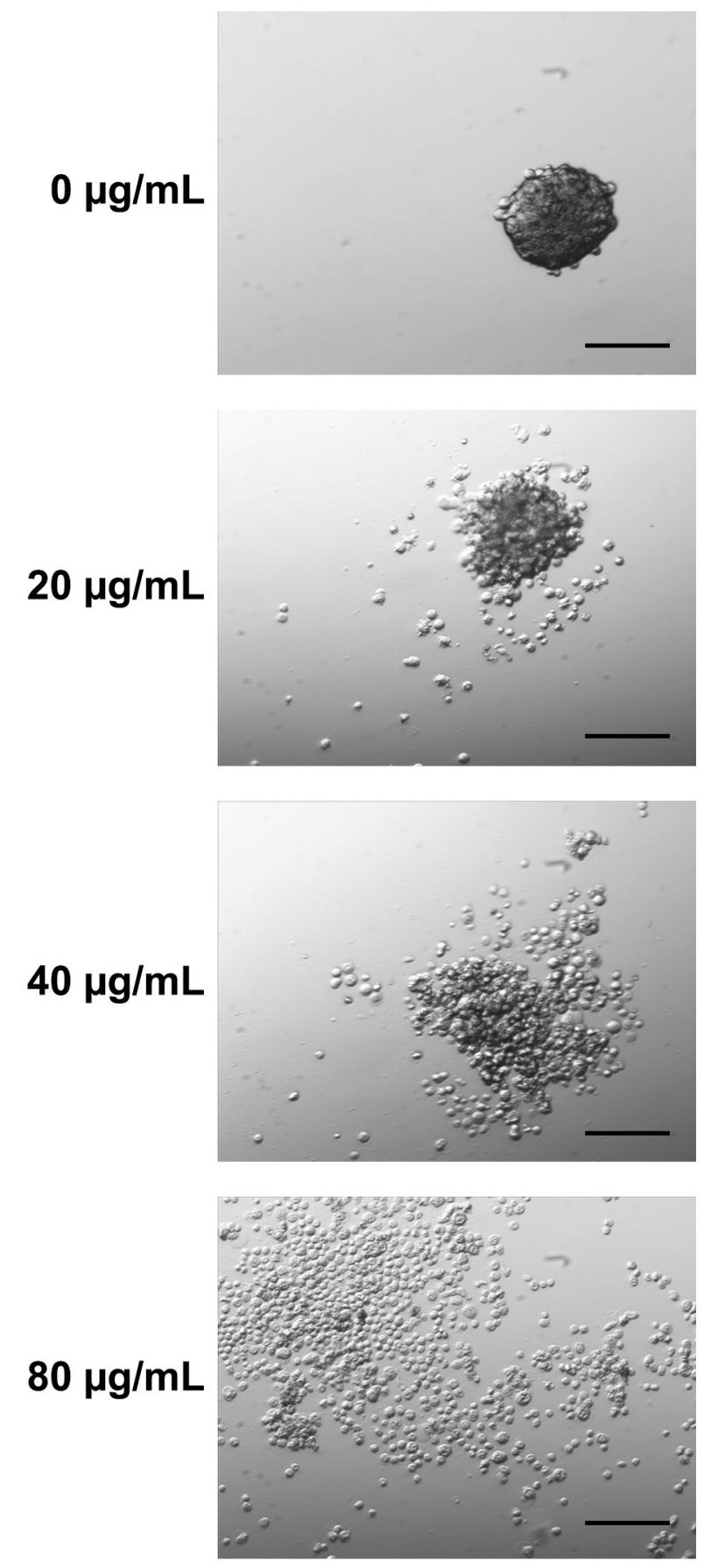

$48 \mathrm{~h}$
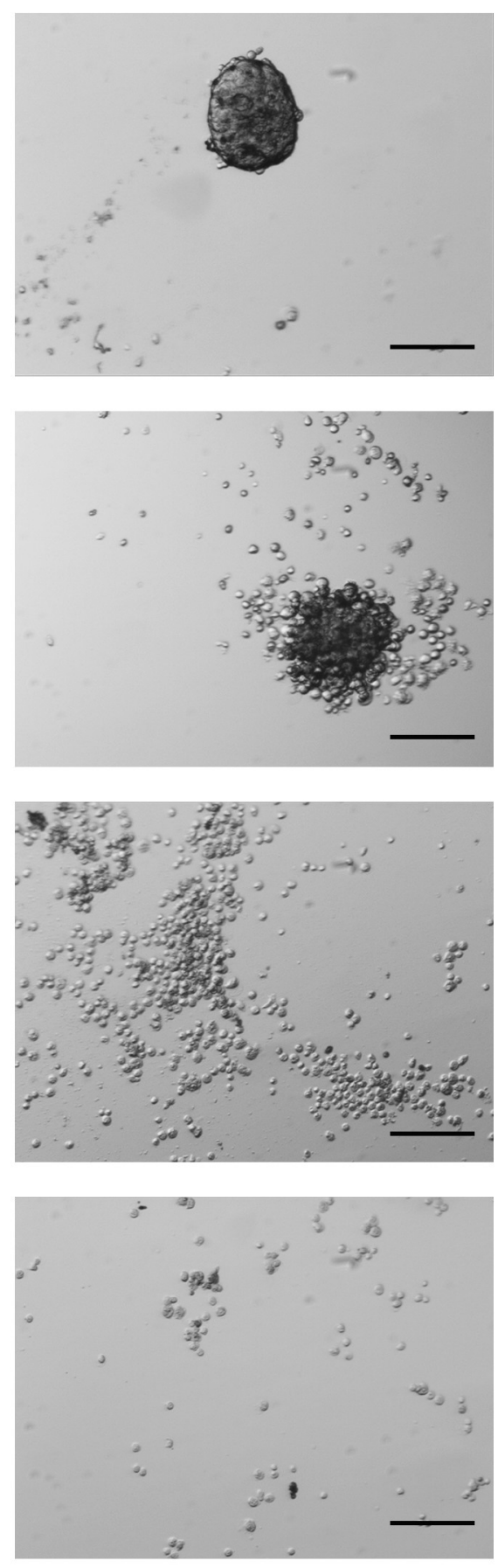
667 Figure 5 MCTS aggregation and morphology was influenced by CTH $(20 \times$ magnification $)$. 668 Control MCTS, growing as a suspension of multicellular aggregates, are shown with no 669 incubation. The multicellular aggregates dissociated with 20, 40 and $80 \mu \mathrm{g} / \mathrm{ml}$ incubations for 24 670 and $48 \mathrm{~h}$. Scale bar $=200 \mu \mathrm{m}$. 


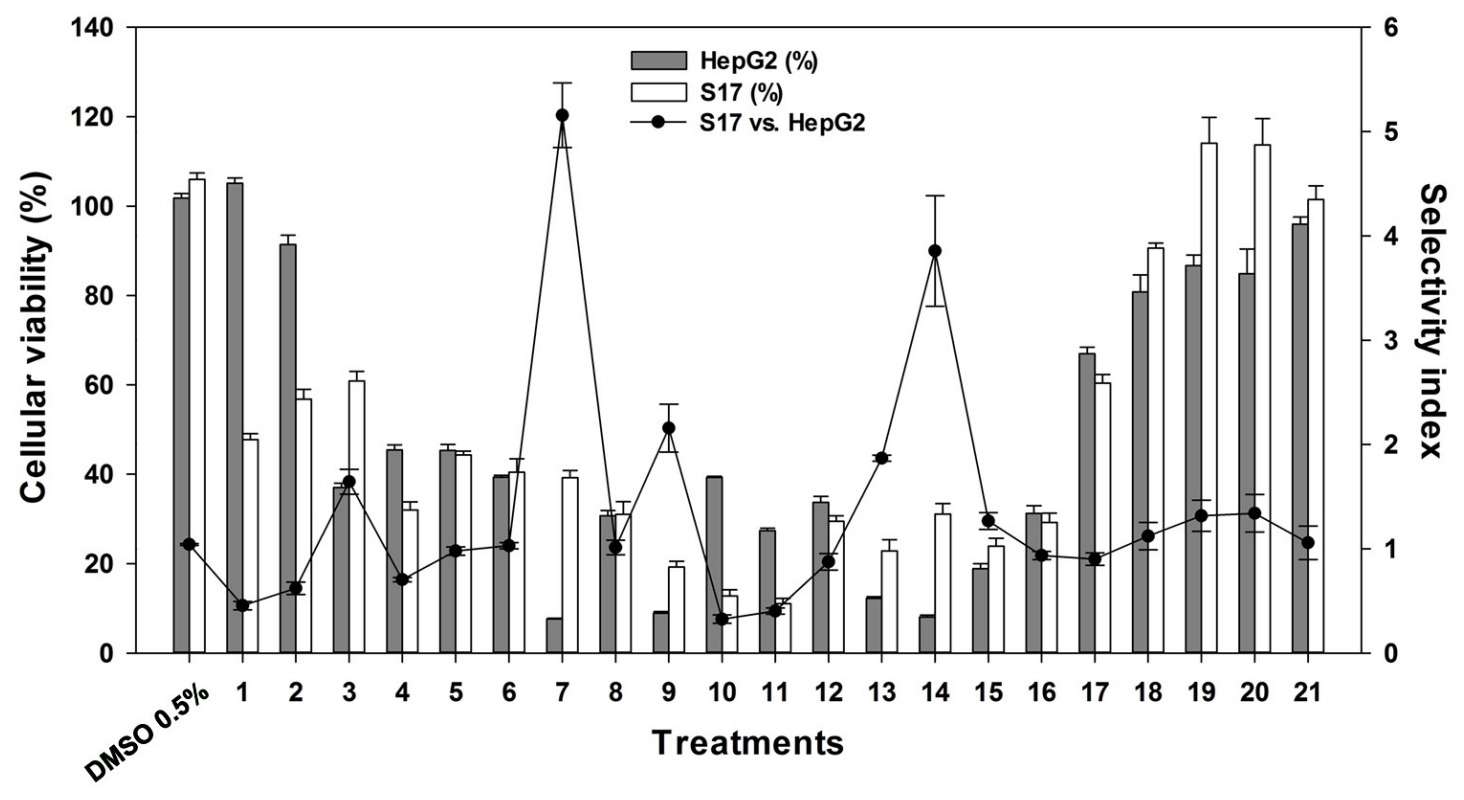

671 Figure 6 Effect of different fractions obtained from $\mathrm{CTH}$, at a concentration of $20 \mu \mathrm{g} / \mathrm{mL}$, on 672 HepG2 and S17 cellular viability. Results are expressed as \% of viability relative to a control 673 containing DMSO $(0.5 \%, \mathrm{v} / \mathrm{v})$. Solid bars and errors represent the average and SEM, 674 respectively $(n=12)$. Selectivity (scatter lines) was calculated using $\mathrm{IC}_{50}$ values of the non-tumor 675 cell line S17 vs. the tumor cell lines. 


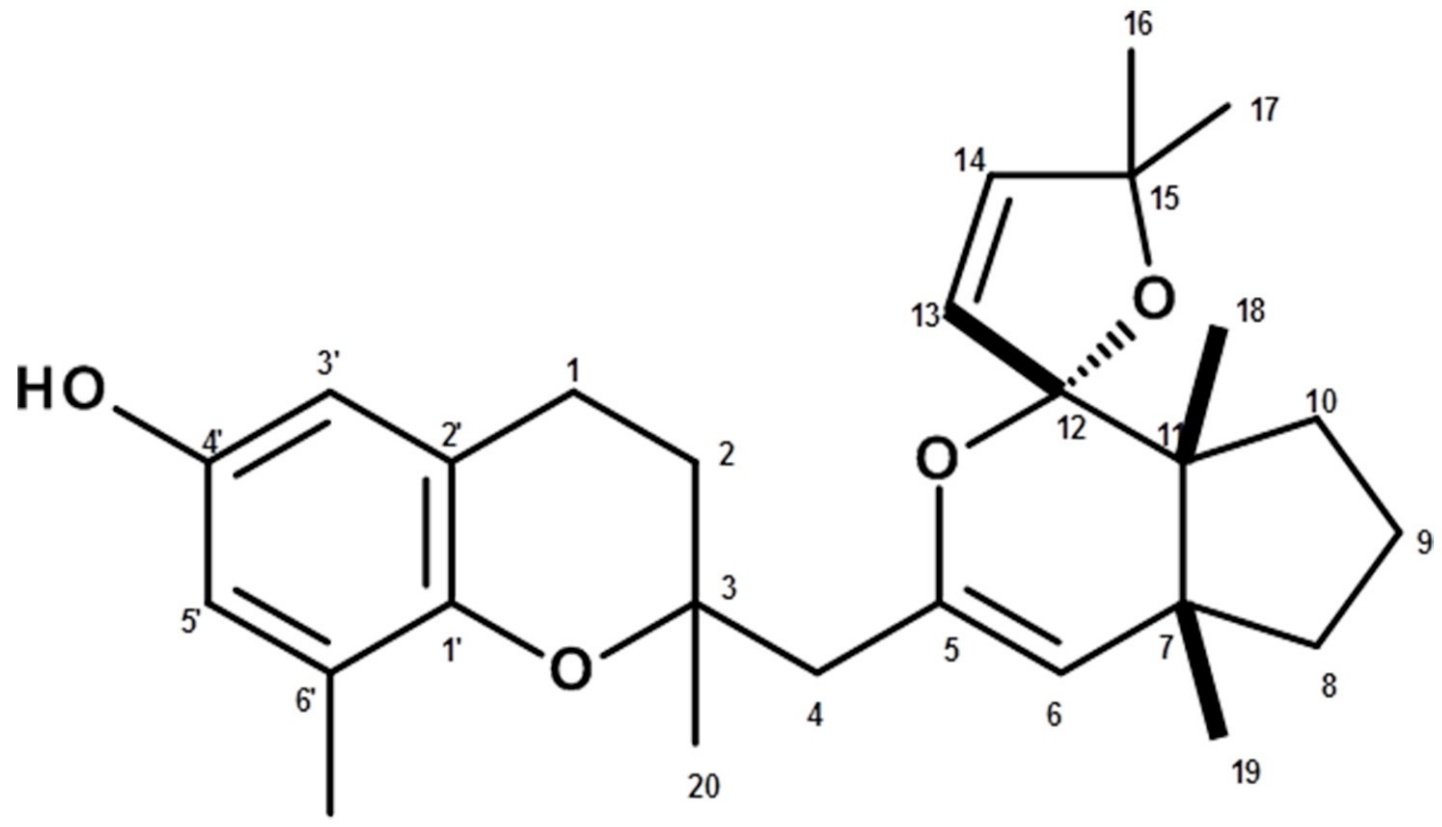

676 Figure 7 Structure of compound $\mathbf{1}$ (demethoxy cystoketal chromane). 